\title{
Hydrodeoxygenation of vanillin over noble metal catalyst supported on biochars: Part II: Catalytic behaviour
}

Jose Luis Santos, ${ }^{a, b, *}$, Päivi Mäki-Arvela ${ }^{b}$, Johan Wärnå ${ }^{b}$, Antonio Monzón ${ }^{c}$, Miguel Angel Centeno $^{a}$, Dmitry Yu. Murzin ${ }^{b}$

${ }^{a}$ Instituto de Ciencia de Materiales de Sevilla, Centro Mixto CSIC-Universidad de Sevilla, 41092 Sevilla, Spain

${ }^{b}$ Johan Gadolin Process Chemistry Centre, Åbo Akademi University, FI-20500 Turku/Åbo, Finland

${ }^{c}$ Instituto de Nanociencia de Aragón (INA) e Instituto de Ciencia de Materiales de Aragón (ICMA), Universidad de Zaragoza-CSIC, 50018 Zaragoza, Spain

*corresponding author: josel.santos@icmse.csic.es

\begin{abstract}
Vanillin hydrodeoxygenation was investigated using noble metal ( $\mathrm{Pd}, \mathrm{Au}, \mathrm{Ru})$ supported on active carbon prepared from waste derived biochars, which were produced via pyrolysis in $\mathrm{CO}_{2}$ atmosphere. Chemical activation with $\mathrm{ZnCl}_{2}$ and $\mathrm{HNO}_{3}$ was also used in the preparation of active carbon to enhance the specific surface area and demineralize material, respectively. Both fresh and spent catalysts were characterized with X-ray diffraction, DRIFTS, zeta potential measurement and HR-TEM. The highest selectivity to p-creosol, 92\% selectivity at complete vanillin conversion after $3 \mathrm{~h}$ was obtained in vanillin hydrodeoxygenation at $100^{\circ} \mathrm{C}$ under 30 bar in hydrogen in water with $\mathrm{Pd} / \mathrm{C}$ catalyst prepared via pyrolysis under $\mathrm{CO}_{2}$ from wine waste and using $\mathrm{ZnCl}_{2}$ as a chemical activation agent. Hydrodeoxygenation activity increased with increasing metal dispersion. A kinetic model including adsorption of vanillin described well the experimental data.
\end{abstract}

Keywords: Active carbon, pyrolysis, noble metal, hydrodeoxygenation, vanillin. 


\section{Introduction}

Hydrodeoxygenation (HDO) of biomass derived bio-oils and their model compounds is currently an important research area due to an urgent need to develop alternative routes to produce liquid transportation fuels, such as cycloalkanes as jet fuel components [1]. Due to the complexicity and instability of bio-oil several model compounds [2], such as guaiacol [3], anisole [4, 5], m-cresol [6] and vanillin [7-10], have been used to study the reaction mechanism of HDO of phenolic compounds and develop active and selective catalysts for these reactions.

Vanillin HDO has been much less investigated compared to guaiacol HDO. This feedstock is also challenging due to its low solubility in hydrophobic solvents. Vanillin contains three oxygen functionalities and it is difficult to be completely deoxygenated. The reaction proceeds via rapid hydrogenation of vanillin to vanillyl alcohol followed by hydrodeoxygenation of vanillyl alcohol to p-creosol, which is typically the main product as demonstrated in [7-19]. There are only few investigations, in which complete deoxygenation of vanillin was demonstrated [19]. Methylcyclohexane was the main product in HDO of vanillin over Ru-ZSM-5 at $170{ }^{\circ} \mathrm{C}$ under 40 bar hydrogen in water as a solvent [19].

The aim in this work was to use noble metal nanoparticles ( $\mathrm{Au}, \mathrm{Pd}$ and $\mathrm{Ru}$ ) supported on biochars prepared from pyrolysis of commercial microcrystalline cellulose and residual biomass (vine shoots) as catalysts in vanillin HDO (Fig. 1). The catalyst preparation and comprehensive characterization results are described in part I [20]. The biochars were produced via pyrolysis in $\mathrm{CO}_{2}$ atmosphere. In addition, chemical activation, such as $\mathrm{ZnCl}_{2}$ and $\mathrm{HNO}_{3}$ treatment were used to enhance the specific surface area and demineralize material, respectively. This work is important to demonstrate suitability of cellulose and 
residual lignocellulosic waste to be applied as a feedstock for preparation of biochar, which will be used as a catalyst support. Expensive noble metals from the spent catalysts can be easily recovered via burning the spent catalyst. As a comparison it was already demonstrated in our previous work the use of commercial active carbon as a support for $\mathrm{Pd}, \mathrm{Ru}, \mathrm{Rh}$ and $\mathrm{Au}$ was already demonstrated in HDO of vanillin. The best catalyst was $\mathrm{Pd} / \mathrm{C}$, which gave in vanillin $\mathrm{HDO} 95 \%$ selectivity to $\mathrm{p}$-creosol at $100^{\circ} \mathrm{C}$ under 30 bar hydrogen in water [9].<smiles>COc1cc(C=O)ccc1O</smiles>

Vanillin

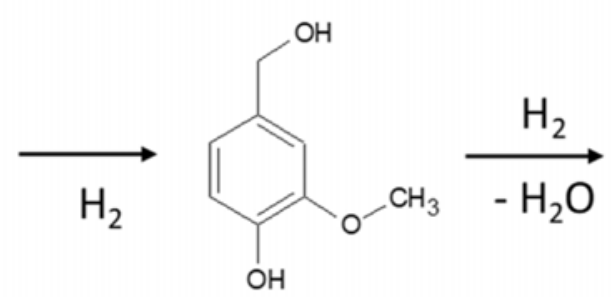

Vanillyl alcohol<smiles>COc1cc(C)ccc1O</smiles>

p-Creosol

Fig. 1. The reaction network for HDO of vanillin.

\section{Experimental}

\subsection{Catalyst preparation}

Synthesis of different catalysts has been reported in detail in part I of this work [20]. In this part the focus will be on elucidation of catalytic behaviour and characterization of spent catalysts. The latter were separated from the reaction medium by filtering, after the reaction has ended. The catalysts were washed in distilled water (ca. 5 litres), and left to dry at room temperature overnight. Thereafter they were recovered and characterized. 


\subsection{Characterization methods}

XRD patterns were acquired at room temperature in a X'Pert Pro PANalytical diffractometer using $\mathrm{Cu} \mathrm{K \alpha}$ radiation (1.5486 $\AA$ ), at a voltage of $45 \mathrm{kV}$ and a current of 40 $\mathrm{mA}$. The patterns were taken at a rate of $0.05^{\circ} / \mathrm{min}$ in the range of $10^{\circ} \leq 2 \theta \leq 90^{\circ}$ using a time per step of 300 seconds. For each diffraction pattern, structural determination was performed by comparison with the database PDF2 ICDD2000 (Powder Diffraction File 2 International Centre for Diffraction Data, 2000).

To evaluate the graphitization degree in the samples by $\mathrm{XRD}$, the stacking height parameter $\left(\mathrm{L}_{\mathrm{c}}\right)$, and the $\mathrm{R}$ value previously defined graphically according to Li et al. [21], were determined.

The stacking heights $\left(\mathrm{L}_{\mathrm{c}}\right)$ was calculated using the empirical Braggs and Scherrer equation [22]:

$$
L_{C}=\frac{K_{C} \cdot \lambda}{\beta_{002} \cdot \operatorname{Cos}\left(\theta_{002}\right)}
$$

where $\lambda$ is the wavelength of incident $\mathrm{X}$-ray (in our case $1.5486 \AA$ for copper $\mathrm{K}_{\alpha}$ radiation); $\Theta 002$ is the peak position of $\{002\}$ band; $\beta 002$ is the full width at half maximum (FWHM) of the corresponding peak and $\mathrm{k}_{\mathrm{c}}$ is a constant depending on X-ray reflection plane $(0.89$ for the $\{002\}$ band). 
The empirical $\mathrm{R}$-value is defined as the ratio of the $\{002\}$ peak intensity relative to the background at the same scattering angle. Lower R-values indicate higher concentrations of single layers, with $\mathrm{R}=1$ indicating no $\{002\}$ peak in the XRD pattern.

Diffuse reflectance infrared Fourier Transform (DRIFTS) spectra were obtained on a JASCO FTIR 6200 spectrometer with a DRIFTS accessory Pike model EASI-DIFF, at room temperature and accumulating 100 scans with a resolution of $4 \mathrm{~cm}^{-1}$.

The average size and size distributions of the metal nanoparticles in the spent catalysts were evaluated by high resolution transmission electron microscopy (HR-TEM) using a FEI Talos electron microscope operating with a $200 \mathrm{kV}$ accelerating voltage, equipped with a Field Emission filament. Digital micrographs were taken with a side mounted Ceta $16 \mathrm{M}$ camera. For HR-TEM preparation, a few milligrams of the spent sample were deposited directly on 300 mesh holey carbon coated copper TEM-grid. The mean particles sizes were estimated from HR-TEM micrographs by single particle measurements of at least 200 particles, selected on the basis of its homogeneity, dispersion and number of particles. The average particle size was estimated assuming the surface distribution calculations:

$$
D_{p}=\frac{\sum n_{i} \cdot d_{i}^{3}}{\sum n_{i} \cdot d_{i}^{2}}
$$

where $d_{i}$ is the measured diameter of the $i^{\text {th }}$ particle, and $n_{i}$ the number of particles with this diameter.

Dispersion of the active phase was also calculated from the average metal particle size determined by TEM, the metal content measured by ICP of the fresh samples and a mathematical model for cuboctahedral particles [23]. 
Morphology of the catalysts was studied by scanning electron microscopy (SEM) using a HITACHI S-4800 electron microscope, equipped with a microanalytical energy dispersive (EDS) detector X-Ray spectrometer. SEM micrographs were taken at a working distance of $4 \mathrm{~mm}$ and a voltage of $2 \mathrm{kV}$. Compositional analysis was performed using EDS, at a working distance of $15 \mathrm{~mm}$, and a voltage of $20 \mathrm{kV}$. Mapping composition was obtained at the same working distance of $15 \mathrm{~mm}$, and a voltage of $5 \mathrm{kV}$.

Acidity of the solids was evaluated by titration. The isoelectric point (IEP) related to bulk acidity was evaluated, using a $\mathrm{pH}$-electrode (Metrohm) according to the procedure described by Markus et al. [24]. The sample (50 mg) was dispersed in $50 \mathrm{ml}$ of distilled water, in the reactor the slurry was continuously stirred by a magnetic stirrer during the measurements, and the $\mathrm{pH}$ was measured with time. The isoelectric point of the sample corresponds to the one measured when achieving a constant $\mathrm{pH}$ value. Prior to measurements the spent samples were thoroughly washed in distilled water (5 litres).

\subsection{Catalytic activity}

Hydrogenation of vanillin (Fluka, $>98 \%$ ) was carried out in a semibatch mode in a Parr reactor, using a $6.6 \cdot 10^{-3} \mathrm{M}$ aqueous solution of vanillin and $50 \mathrm{mg}$ of the catalyst (sieved below $60 \mu \mathrm{m})$. Once the vanillin solution and the catalyst were loaded in the reactor, thereafter an inert gas (Ar, 10 bars) was flushed into the reactor to purge it and to remove air. Then, the reactive atmosphere (hydrogen, AGA, 99.999\%) was introduced, the temperature was raised to the desired one $\left(100{ }^{\circ} \mathrm{C}\right)$ and the total pressure was increased to the working one (30 bar). The reaction was performed with a stirring rate of $900 \mathrm{rpm}$ to suppress the mass transfer limitations. 
During the reaction, the samples were taken at different times from the reactor and analyzed by HPLC using an Agilent Technologies (1100 series) instrument. HPLC was equipped with a UV-Vis photo diode array detector set at $273 \mathrm{~nm}$, and a Quaternary pump. The column used was Ultra Techsphere ODS-5u (C18), $250 \mathrm{~mm} \cdot 4.6 \mathrm{~mm}$. The mobile phase composed of methanol (B) and $0.5 \%$ phosphoric acid (A), was flowing at $1 \mathrm{~mL} \cdot \mathrm{min}-1$. The following gradient was used: A:B 85:15, $10 \mathrm{~min}$, 25:25 (18 min), 30:70 (25 min), 30:0 (30 $\min$ ) and 35:100 (35 min). The sample injection volume and retention time were $5 \mu \mathrm{L}$ and $50 \mathrm{~min}$, respectively [25].

\section{Results and discussion}

\subsubsection{Characterization of the spent catalysts}

The obtained XRD patterns of spent solids and some of the possible reactants, intermediates and products are illustrated in Fig. 2. Although the spent catalysts do not exhibit significant modifications compared to the fresh ones [20], it is possible to observe some differences in the crystallinity of the solids by studying the stacking heights $\left(\mathrm{L}_{\mathrm{c}}\right)$ parameters and the empirical R-values.

In all cases, the spent catalyst exhibits higher crystallite stacking heights $\left(\mathrm{L}_{c}\right)$ parameter values, leading to coke-like graphitic chars (Table 1). Likewise, similar R-values or higher were found for spent mesoporous catalysts, displaying biochars catalyst with a larger number of carbon layers at the surface. However, this trend is opposite for the microporous materials, which have similar or smaller R-values for the spent catalysts. This could indicate that the microporous chars after the reaction are solids comprising a smaller number of carbon sheets and indicating a possible exfoliation during the reaction. Such 
exfoliation could be altered by the presence of different reaction species deposited on the surface of the catalyst, which could be carbonized under the reaction conditions. This in turn results in higher values of carbon layers on the surface, as has been extensively proposed in the literature previously [26, 27], leading to deactivation by coking.

\section{Table 1}

Structural parameters calculated from XRD.

\begin{tabular}{|c|c|c|c|}
\hline $\begin{array}{c}\text { Sample } \\
\text { Fresh(*), Post Reaction }\end{array}$ & $\begin{array}{l}\text { Average Particle Size } \\
\text { (XRD, nm) }\end{array}$ & $\begin{array}{c}\text { Lc Parameter } \\
(\AA)\end{array}$ & $\begin{array}{l}\text { R value } \\
(002)\end{array}$ \\
\hline $\mathrm{Pd} / \mathrm{C}_{\text {cel }} \mathrm{CO}_{2}$ & $37^{*}$, n.d. & $13^{*}$, n.d. & $1.5^{*}$, n.d. \\
\hline $\mathrm{Pd} / \mathrm{C}_{\text {cel }} \mathrm{ZnCl}_{2} \mathrm{CO}_{2}$ & $22^{*}$, N.A. & $12^{*}, 13$ & $1.5^{*}, 1.5$ \\
\hline $\mathrm{Pd} / \mathrm{C}_{\text {vin }} \mathrm{CO}_{2}$ & $32^{*}, 25$ & $12^{*}, 14$ & $1.9^{*}, 2$ \\
\hline $\mathrm{Pd} / \mathrm{C}_{\text {vin }} \mathrm{ZnCl}_{2} \mathrm{CO}_{2}$ & N.A. ${ }^{*}$, N.A. & $15^{*}, 16$ & $1.7^{*}, 1.6$ \\
\hline $\mathrm{Ru} / \mathrm{C}_{\mathrm{cel}} \mathrm{CO}_{2}$ & $12^{*}, 8$ & $15^{*}, 15$ & $1.7^{*}, 1.3$ \\
\hline $\mathrm{Ru} / \mathrm{C}_{\text {cel }} \mathrm{ZnCl}_{2} \mathrm{CO}_{2}$ & N.A. ${ }^{*}$, N.A. & $13^{*}, 15$ & $1.7^{*}, 1.6$ \\
\hline $\mathrm{Ru} / \mathrm{C}_{\mathrm{vin}} \mathrm{CO}_{2}$ & N.A. ${ }^{*}$, N.A. & $13^{*}, 16$ & $2.3^{*}, 1.4$ \\
\hline $\mathrm{Ru} / \mathrm{C}_{\mathrm{vin}} \mathrm{ZnCl}_{2} \mathrm{CO}_{2}$ & N.A. ${ }^{*}$, N.A. & $14^{*}, 17$ & $1.7^{*}, 1.6$ \\
\hline $\mathrm{Au} / \mathrm{C}_{\mathrm{cel}} \mathrm{CO}_{2}$ & $6^{*}$, N.A. & $13^{*}, 15$ & $1.7^{*}, 1.7$ \\
\hline $\mathrm{Au} / \mathrm{C}_{\mathrm{cel}} \mathrm{ZnCl}_{2} \mathrm{CO}_{2}$ & $25^{*}$, n.d. & $13^{*}$, n.d. & $1.5^{*}$, n.d. \\
\hline $\mathrm{Au} / \mathrm{C}_{\mathrm{vin}} \mathrm{CO}_{2}$ & $8^{*}, 24.2$ & $12^{*}, 15$ & $2.0^{*}, 2.2$ \\
\hline $\mathrm{Au} / \mathrm{C}_{\mathrm{vin}} \mathrm{ZnCl}_{2} \mathrm{CO}_{2}$ & $21^{*}, 13$ & $13^{*}, 14$ & $1.8^{*}, 1.6$ \\
\hline
\end{tabular}

$* \mathrm{NA}=$ Not available. ${ }^{*}$. $. \mathrm{d} .=$ Not determined

In addition, spent catalysts exhibits extra diffractions peaks centred at 21, 26.8 and $28.5^{\circ} 2 \theta$ of unknown crystalline species. Looking for an explanation for this, XRD of some reactants, intermediates and products was measured, (Fig. 2d). As shown in this Figure, 
vanillyl alcohol, p-cresol, and vanillin show intense diffraction peaks between 10 and $30^{\circ} 2 \theta$, coinciding with the amorphous carbon peak associated with $\{002\}$ family planes. Although

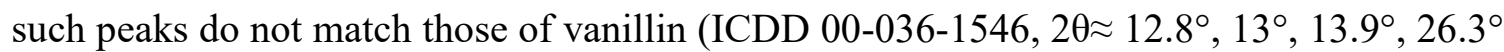
and $26.6^{\circ}$ ), they should be assigned to organic species absorbed on the surface of the catalysts, probably related with other stable intermediates or products different the measured ones (p-creosol or vanillyl alcohol). As will be shown below, some DRIFTS and SEM evidences support this possibility.

At the same time, as demonstrated by Li et al. [28], the diffraction angles and FWHMs are strongly influenced by the distortion factors [29]. Evidently, evaluation of the $\mathrm{L}_{\mathrm{c}}$ values for the spent catalysts is even more complicated due to possible distortions induced by the presence of nanoparticles.
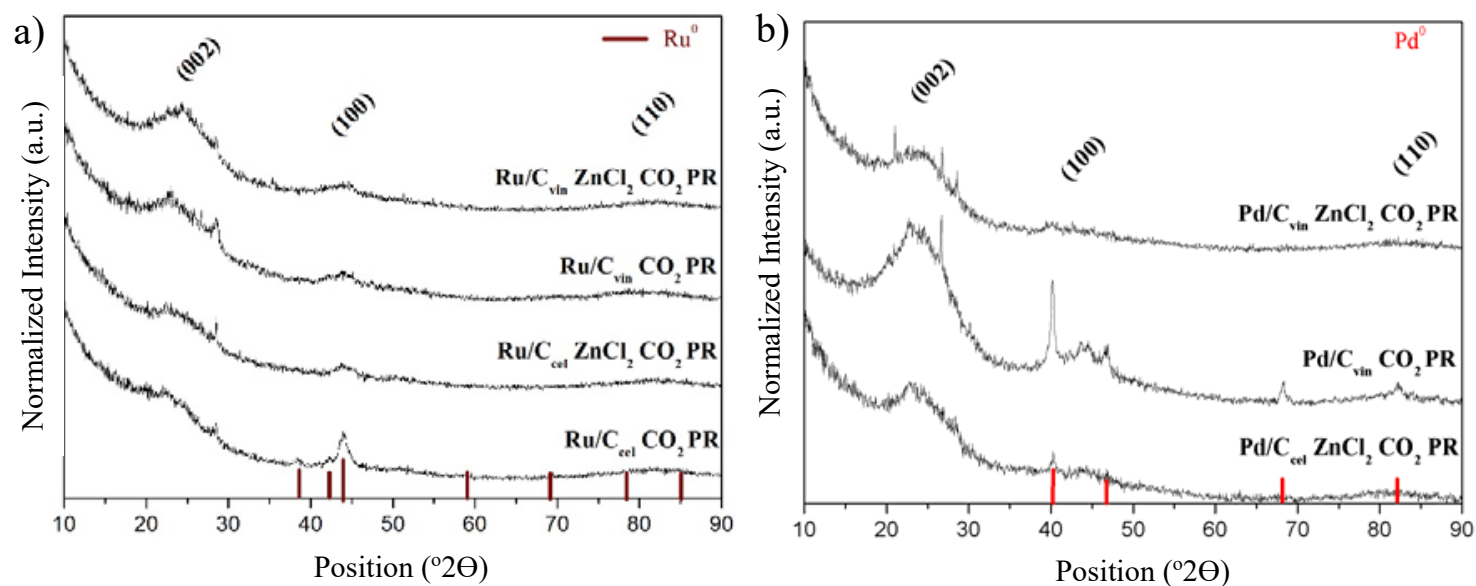

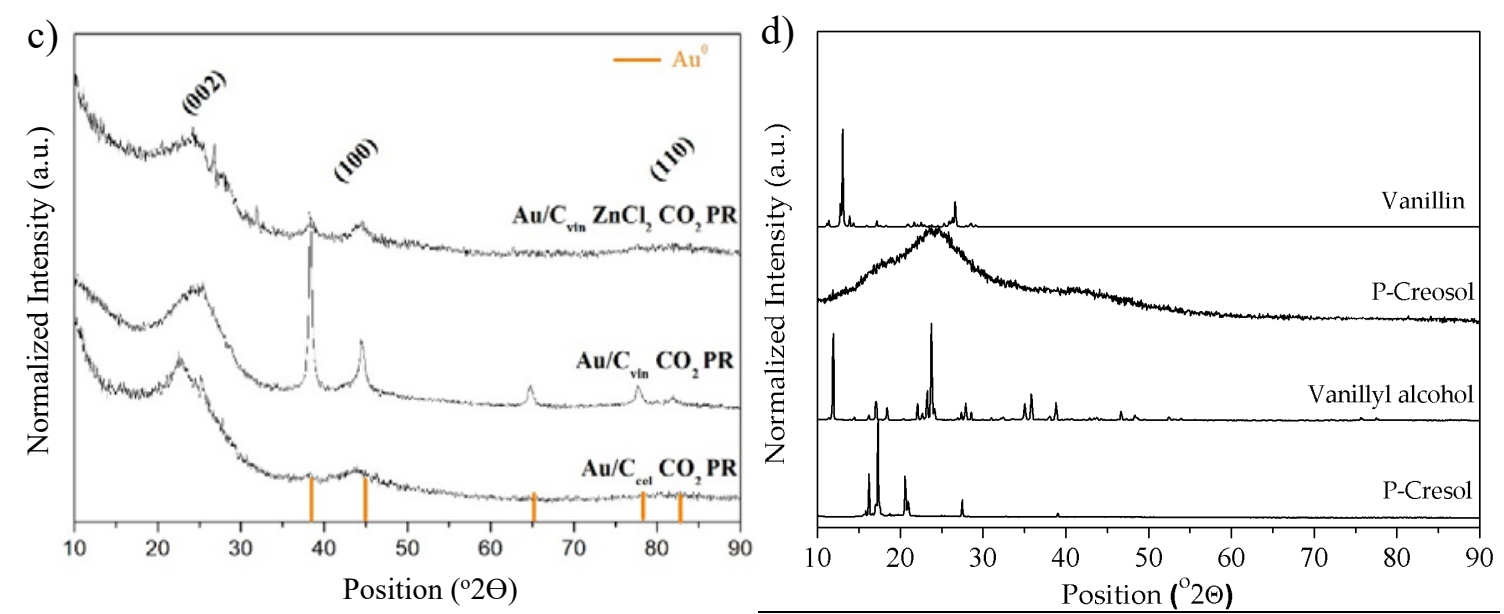

Fig. 2. XRD of the post reaction samples a) ruthenium, b) palladium, c) gold and d) reaction patterns.

Additionally, several diffraction peaks ascribed to the metal phase appear in the diffraction patterns of the spent catalysts, all of them corresponding to completely reduced $\mathrm{Pd}, \mathrm{Ru}$ and $\mathrm{Au}$ species (Figs 2a-c). No peaks ascribed to any other crystalline species were visible, demonstrating no re-oxidation processes under the operating conditions and complete reduction of the metallic precursors even after reaction.

Concerning the metallic nanoparticles size, for ruthenium and palladium catalyst, the calculated average size was always lower in the spent catalysts than in the corresponding fresh ones. The situation was different for gold catalysts. It was found that the particle size for gold in the spent catalysts supported on cellulose chars and vine shoot char treated with zinc chloride, was smaller than in the fresh catalysts. However, this did not happen for the catalyst supported on untreated vine shoot char, which exhibited clear sintering. Although a more detailed study is necessary, at this point leaching might be mist probably ruled out even if it cannot be completely excluded. Redispersion of the metallic nanoparticles under reaction conditions, leading to smaller particles size and confirmed by TEM has been extensively 
reported previously for noble metal nanoparticles under reductive atmospheres $\left(\mathrm{H}_{2}, \mathrm{CO}\right.$, etc. $)$ and high temperatures or pressures [29-31].

The DRIFTS spectra of the obtained spent char catalysts are shown in Fig. 3. A similar conclusion can be deduced from analysis of the spectra of all spent samples. The presence of new functional groups is evidenced on the surface, probably associated with adsorption of some reaction intermediates or products, although the partial oxidation of the carbonaceous surface cannot be fully discarded. The new bands detected are associated mostly with the oxygenated species at: $3417 \mathrm{~cm}^{-1}$ (probably due to $\mathrm{OH}$ groups of aliphatic alcohols), 2947, 2902, 2870, 2727, 2528 (probably aliphatic $\mathrm{C}-\mathrm{H}$ bonds), $1714(\mathrm{C}=\mathrm{O}), 1620$ (bending H-O-H of adsorbed water), 1435 (aliphatic C-C), 1330, $1160(\mathrm{C}-\mathrm{O}) \mathrm{cm}^{-1}$. These bands associated with the appearance of new oxygenated groups indicate presence of organic species, probably unidentified reaction intermediates, different from vanillin alcohol, pcresol, and p-creosol, compounds which DRIFTS spectra are not related to the position of these new bands (Fig. S1).

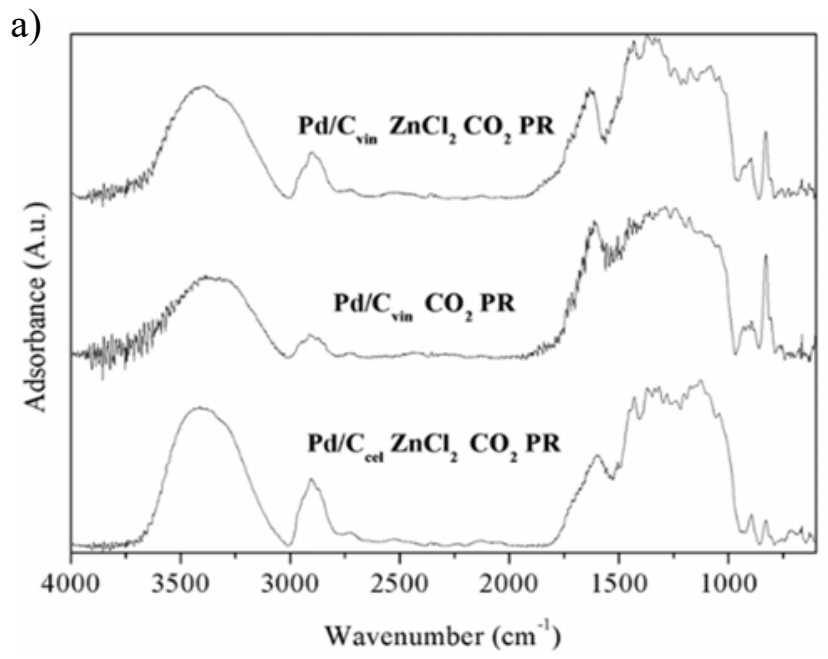



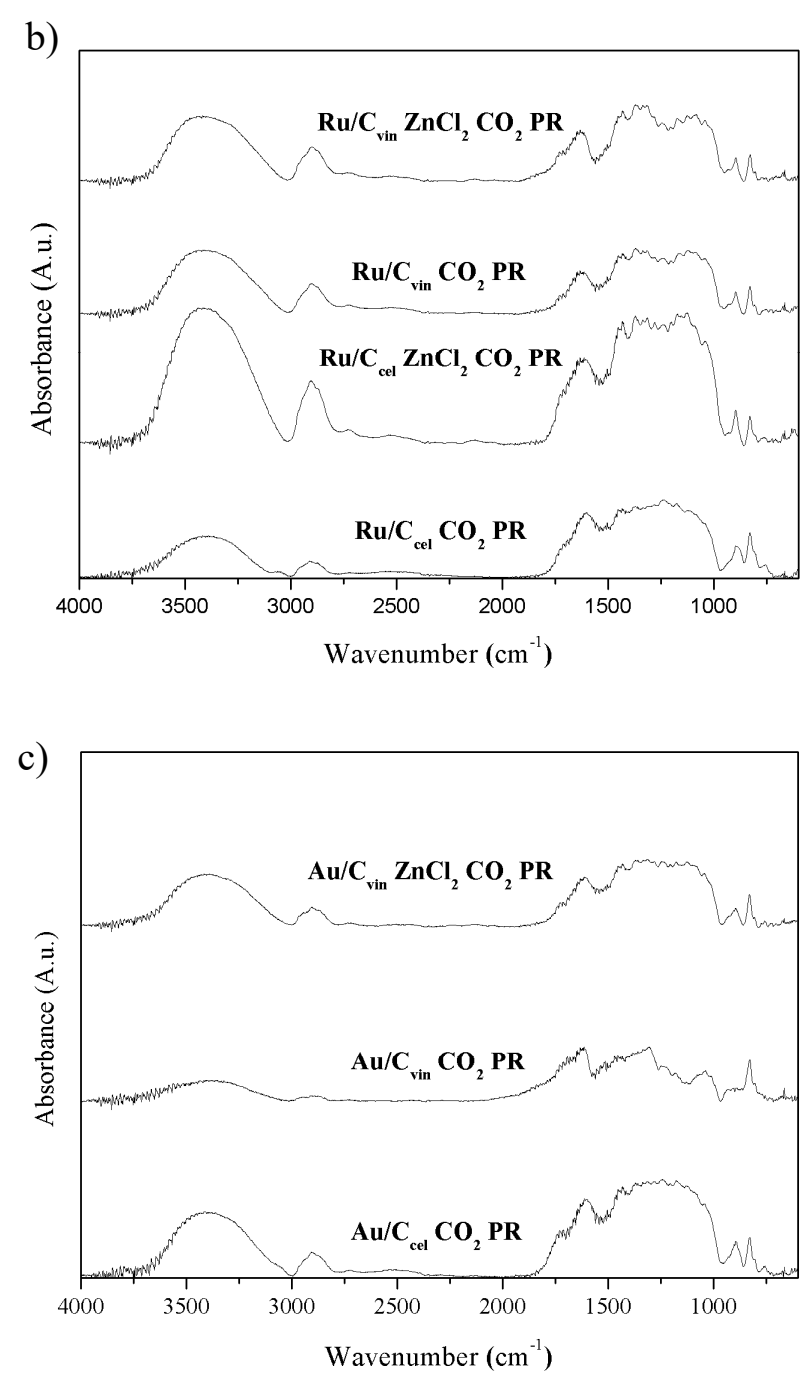

Fig. 3. DRIFTS spectra of spent a) palladium, b) ruthenium and c) gold catalysts.

The difference spectra between the fresh and spent samples are presented in Fig. 4 for Ru-containing spent catalysts and in Supporting Information (Fig. S2) for other materials. It can be also stated that adsorption of such species could imply interactions with the aromatic carbon structure, since negative bands at 930,820 and $650 \mathrm{~cm}^{-1}$, associated with $\mathrm{CH}$ bonds in these aromatic structures are visible. 


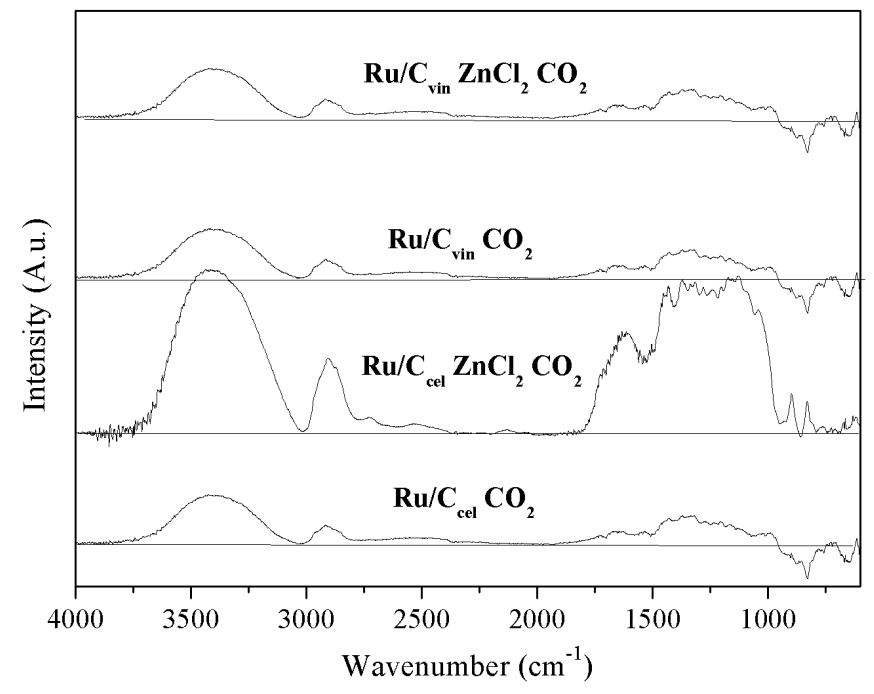

Fig. 4. DRIFTS difference spectra of ruthenium catalysts.

TEM micrographs and metal particle size distribution for the spent catalysts are shown in Fig. 5. A good correlation was achieved between the average metal particle size determined by TEM and that obtained by XRD using the Scherrer's equation (Table 1). However, a higher discrepancy is obtained for Pd catalysts. The statistical analysis of at least 250 particles of the spent catalysts is also shown in Fig. 5. As seen in this Figure, the mesoporous catalysts (those activated with $\mathrm{ZnCl}_{2}$ [20]) with a higher specific surface exhibit smaller particles sizes and a higher dispersion of the active phase even after the reaction than microporous ones. 

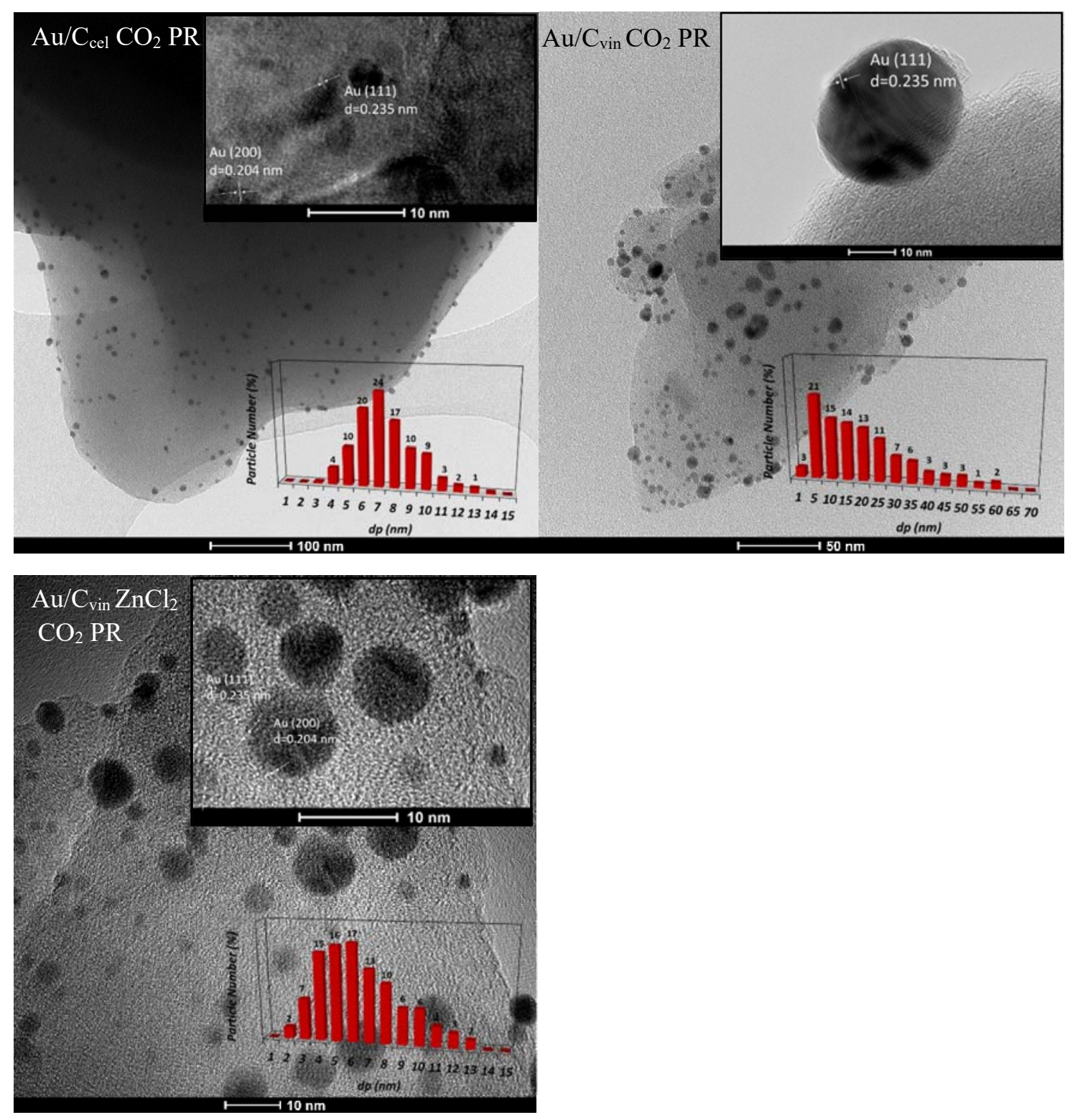

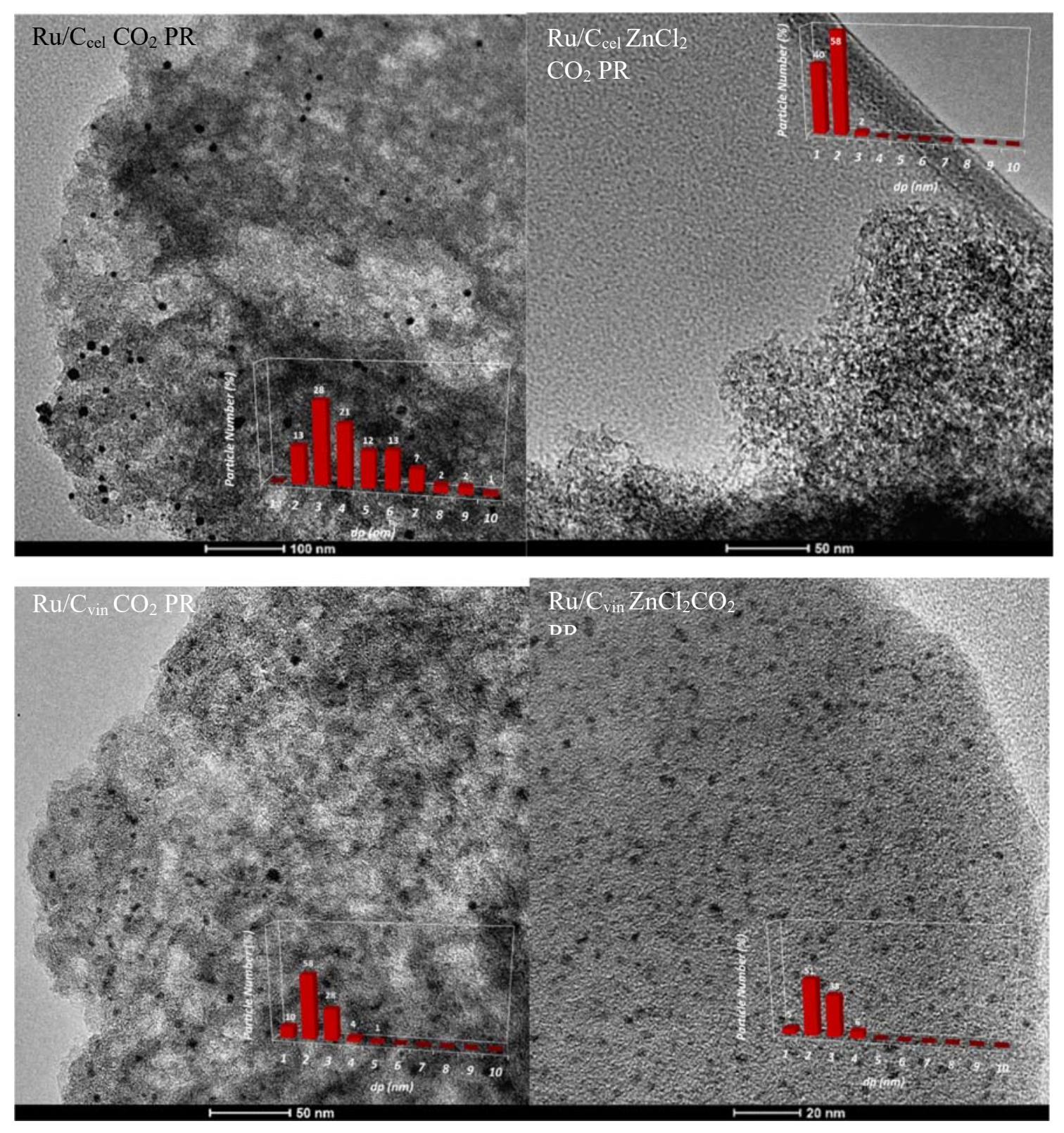

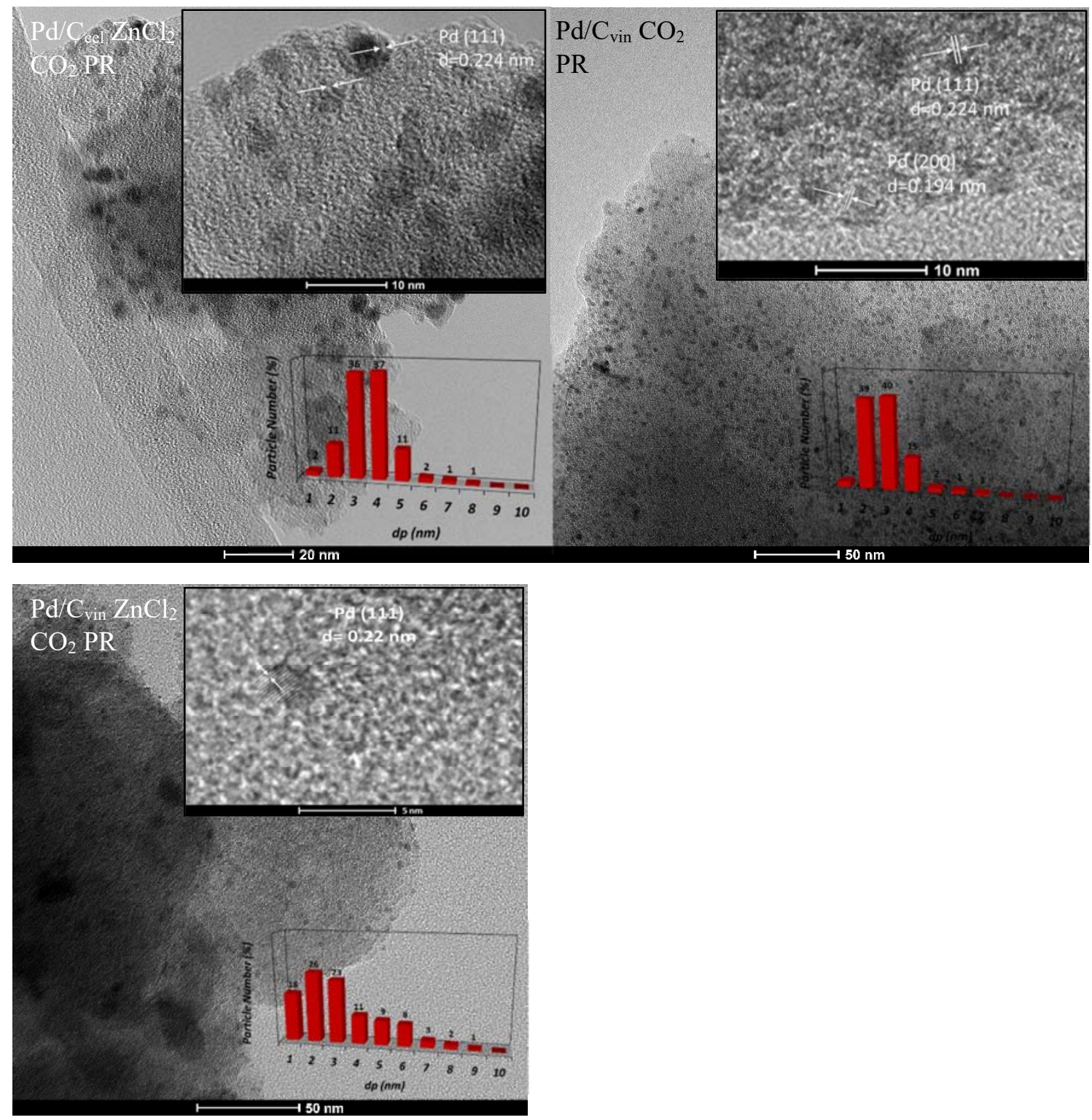

Fig. 5. TEM and HRTEM images of metal nanoparticles after the reaction.

HRTEM was carried out for some samples. HRTEM image in Fig. 5 for the Pd/C $\mathrm{ZnCl}_{2} \mathrm{CO}_{2}$ is shown as a representative example of metallic $\mathrm{Pd}$ nanoparticles showing a discrete lattice-fringe of the face centered cubic (fcc) Pd crystal with a d-spacing of 0.224 $\mathrm{nm}$, which is in agreement with the lattice spacing of the $\{111\}$ plane reported in the literature $[32,33]$. 
In $\mathrm{Au} / \mathrm{C}_{\mathrm{vin}} \mathrm{ZnCl}_{2} \mathrm{CO}_{2}$, the lattice spacing of $0.235 \mathrm{~nm}$ is in good agreement with that of the bulk $\mathrm{Au}\{111\}$ plane $(0.2355 \mathrm{~nm})$. Since the lattice planes of each particle are randomly arranged, different lattice parameters of each crystallography face, as $\{200\}$ plane with dspacing of $0.203 \mathrm{~nm}$. reported in literature [34] can be found and shown in the XRD pattern of gold (Cubic, ICDD 00-004-0784).

For the spent ruthenium catalysts, it was observed that mean Ru particles size decreased more with less acidic supports indicating better ruthenium redispersion and formation of small particles. On the other hand, more acidic supports with more acidic carboxylic groups retard mobility of $\mathrm{Ru}$ [34]. It can be seen from Fig. 5 that the spent ruthenium catalysts exhibited semi-spherical nanoparticles with the size less than $5 \mathrm{~nm}$ and several distinguishable crystalline planes. The interplanar distances measured as indicated in Fig. 5 were: $0.20 \mathrm{~nm}$, and $0.23 \mathrm{~nm}$, corresponding to the planes: $\{101\}$ and $\{100\}$ of metallic $\mathrm{Ru}$ (hcp) phase (hexagonal, ICDD 00-006-0663), respectively [35]. 


\section{Table 2}

Mean particle size, isoelectric point and calculated dispersion.

\begin{tabular}{ccc}
\hline $\begin{array}{c}\text { Catalyst } \\
\text { Fresh(*), Post Reaction }\end{array}$ & $\begin{array}{c}\text { Average particle } \\
\text { size (TEM, nm) }\end{array}$ & $\begin{array}{c}\text { Isoelectric Point } \\
(\mathrm{pH})\end{array}$ \\
\hline $\mathrm{Pd} / \mathrm{C}_{\mathrm{cel}} \mathrm{CO}_{2} \mathrm{PR}$ & $19^{*}$, n.d. & $5.8^{*}$, n.d. \\
$\mathrm{Pd} / \mathrm{C}_{\mathrm{cel}} \mathrm{ZnCl}_{2} \mathrm{CO}_{2} \mathrm{PR}$ & $6^{*}, 4.2$ & $6.2^{*}, 4.8$ \\
$\mathrm{Pd} / \mathrm{C}_{\mathrm{vin}} \mathrm{CO}_{2} \mathrm{PR}$ & $13.8^{*}, 3.5$ & $6.6^{*}, 5.0$ \\
$\mathrm{Pd} / \mathrm{C}_{\mathrm{vin}} \mathrm{ZnCl}_{2} \mathrm{CO}_{2} \mathrm{PR}$ & $6.9^{*}, 5$ & $6.7^{*}, 4.7$ \\
$\mathrm{Ru} / \mathrm{C}_{\mathrm{cel}} \mathrm{CO}_{2} \mathrm{PR}$ & $9.6^{*}, 4.8$ & $5.5^{*}, 5$ \\
$\mathrm{Ru} / \mathrm{C}_{\mathrm{cel}} \mathrm{ZnCl}_{2} \mathrm{CO}_{2} \mathrm{PR}$ & $2.7^{*}, 2.1$ & $6.4^{*}, 4.9$ \\
$\mathrm{Ru} / \mathrm{C}_{\mathrm{vin}} \mathrm{CO}_{2} \mathrm{PR}$ & $3.9^{*}, 2.8$ & $6.5^{*}, 4.8$ \\
$\mathrm{Ru} / \mathrm{C}_{\mathrm{vin}} \mathrm{ZnCl}_{2} \mathrm{CO}_{2} \mathrm{PR}$ & $3.6^{*}, 2.9$ & $6.4^{*}, 4.2$ \\
$\mathrm{Au} / \mathrm{C}_{\mathrm{cel}} \mathrm{CO}_{2} \mathrm{PR}$ & 8.43 & $5.3^{*}, 5$ \\
$\mathrm{Au} / \mathrm{C}_{\mathrm{cel}} \mathrm{ZnCl}_{2} \mathrm{CO}_{2} \mathrm{PR}$ & $24.7^{*}$, n.d. & $5.1^{*}$, n.d. \\
$\mathrm{Au} / \mathrm{C}_{\mathrm{vin}} \mathrm{CO}_{2} \mathrm{PR}$ & $8.7^{*}, 36.4$ & $7.2^{*}, 4.8$ \\
$\mathrm{Au} / \mathrm{C}_{\mathrm{vin}} \mathrm{ZnCl}_{2} \mathrm{CO}_{2} \mathrm{PR}$ & $20.9^{*}, 12$ & $7^{*}, 4.9$
\end{tabular}

n.d. not determined

The particle size distribution of the spent catalysts exhibit some changes compared to the fresh ones (Fig. 6), namely more particles with a smaller size, and a smaller average size. 

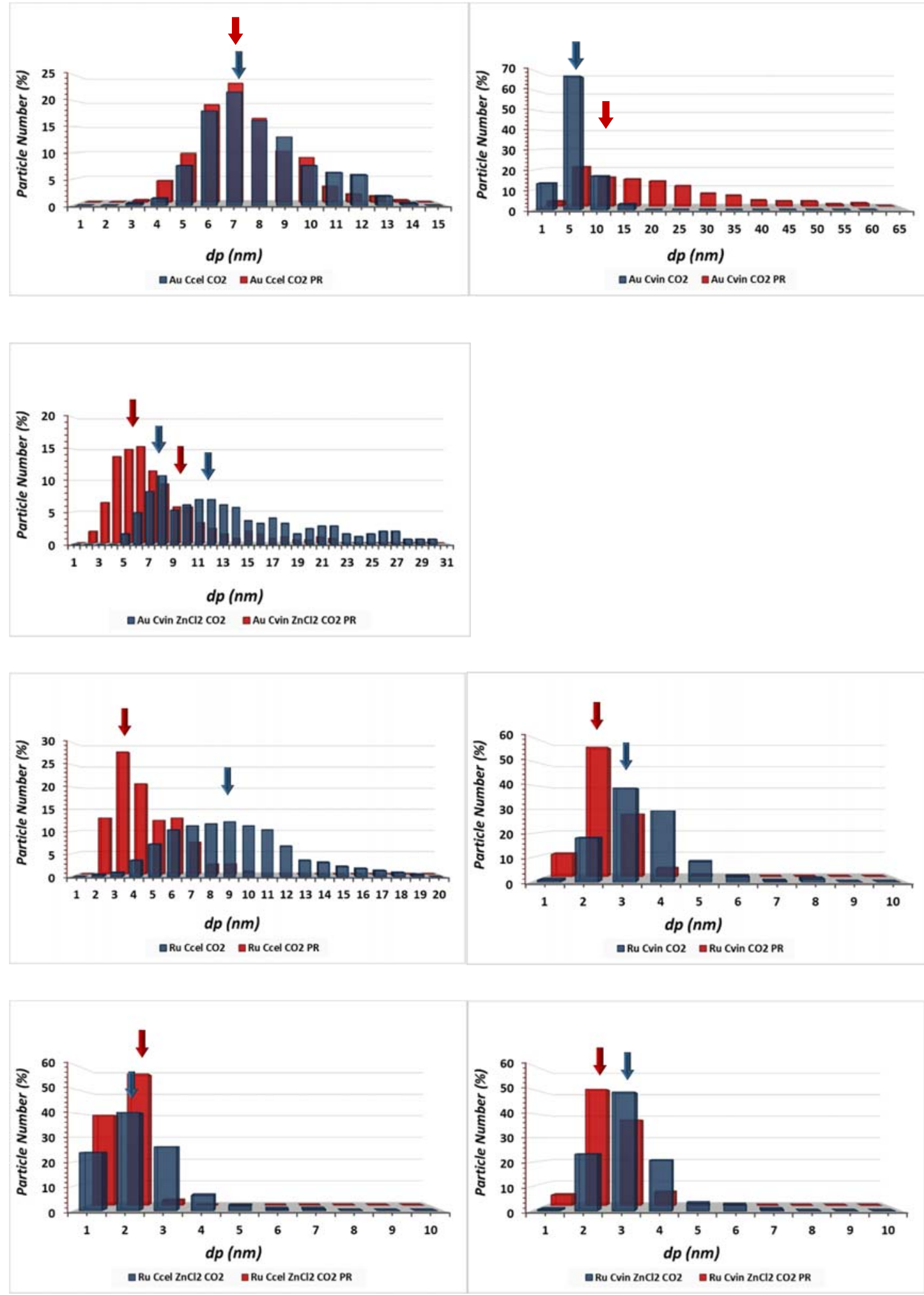

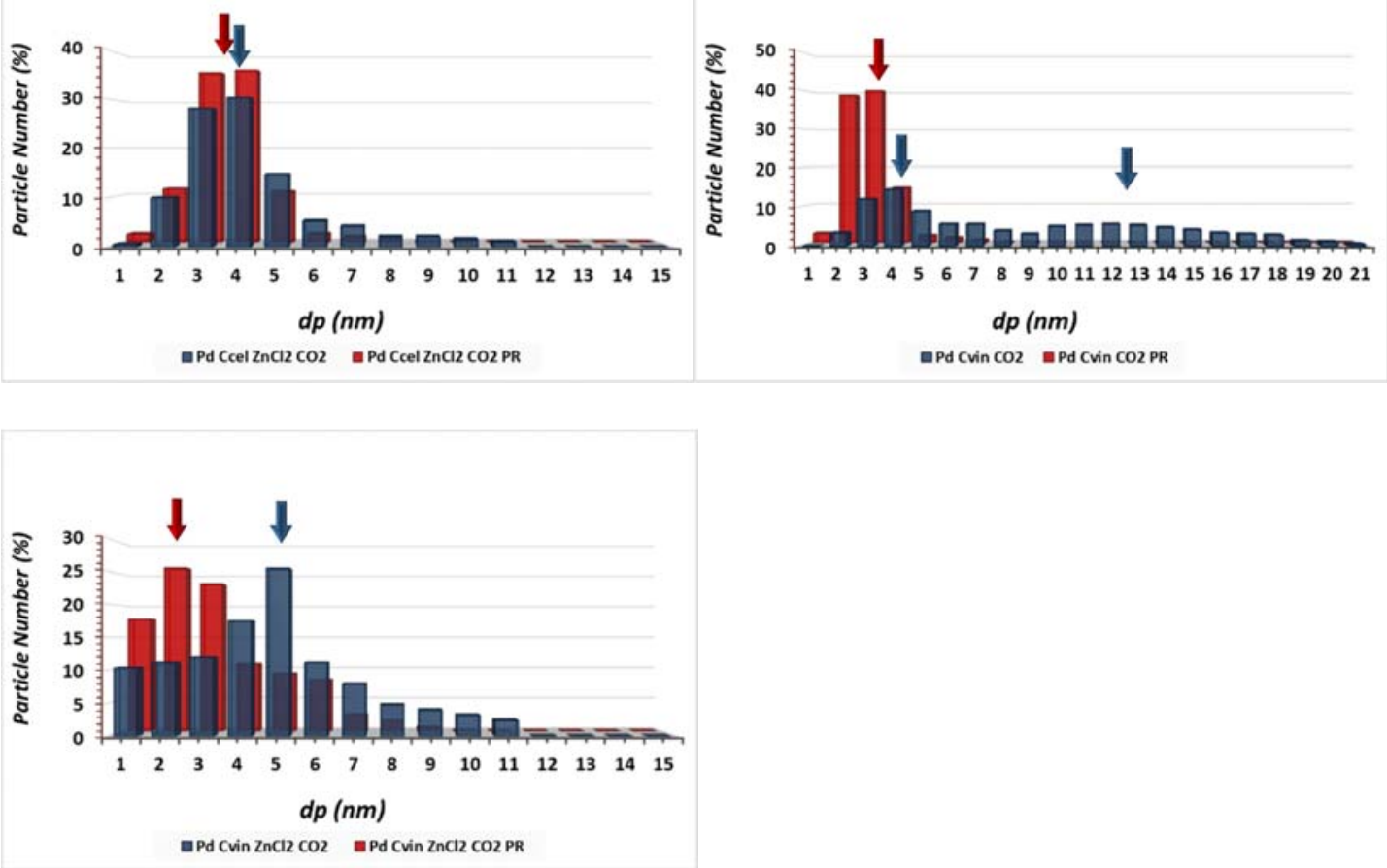

Fig. 6. Particle size distribution of the fresh and spent catalysts.

The observed results suggest various mechanisms which lead to metal redispersion. For Pd and Ru catalysts supported onto char from vine shoot, the average metal particle size decreased indicating redispersion of the metal after the reaction (Table 2). This effect is governed by two mechanisms, as described by Bartholomew and Farrauto [36]. The entire crystallite can migrate over the support surface, or metal atoms or molecule clusters can be detached from the crystallites [37-39]. Atomic or small cluster migration is favoured at low temperatures. On the other hand, metal sintering occurring at higher temperatures and creating larger crystallites [40], was only observed in the $\mathrm{Au} \mathrm{C}_{\mathrm{vin}} \mathrm{CO}_{2}$ spent catalyst.

As mentioned above leaching of larger metal particles giving monomodal distributions of smaller particle size cannot be ruled out as will be shown in SEM microscopy 
below. Thus results of the current work can be explained as a combination of both effect, i.e. the metal particles are split giving smaller particles and larger particles are leached from the surface of the catalyst.

The morphological features of the spent catalysts were examined by SEM micrographs (Fig. 7), while the chemical composition was analysed by EDS analysis (Table 3). As shown above, vine shoot biochar catalyst exhibits after the reaction a clearly visible porous structure. Chemically activated biochar catalyst diminishes significantly the presence of residual inorganic matter due to leaching during the reaction (Table 3), unblocking partially the catalyst surface. However, presence of some organic species from adsorption of reactants on the catalytic surface is clearly visible in the micrographs of the spent catalysts in good agreement with DRIFTS and XRD observations.

Furthermore, according with previously characterization results, the surface morphology of the spent catalysts was similar to the fresh ones [20], suggesting no modifications during vanillin HDO reaction. SEM micrographs also confirm a less heterogeneous metal distribution for ruthenium and gold spent catalysts, especially for spent palladium catalysts, where all metallic islands present in the fresh catalysts have disappeared after the reaction, which is consistent with the TEM. 

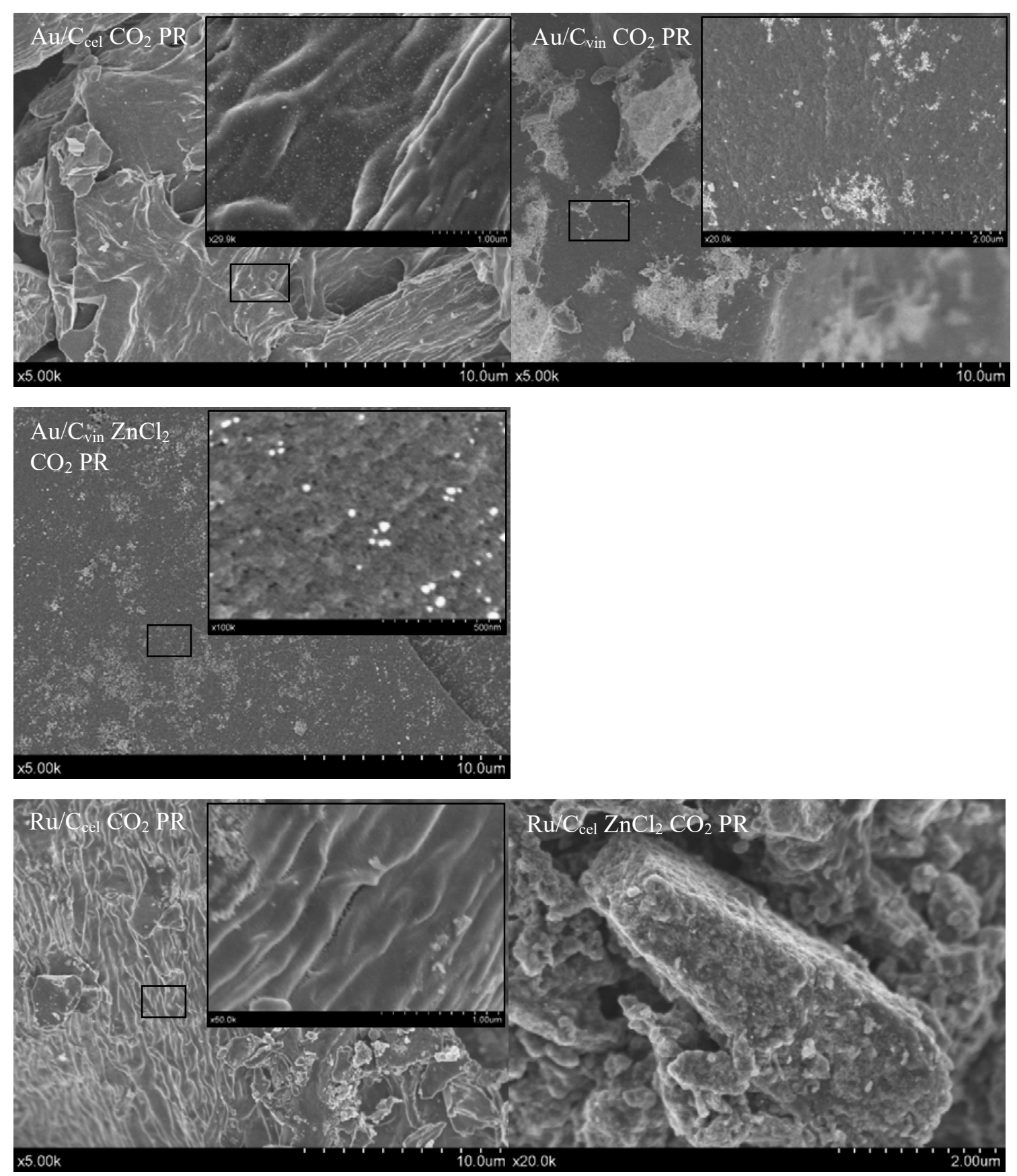

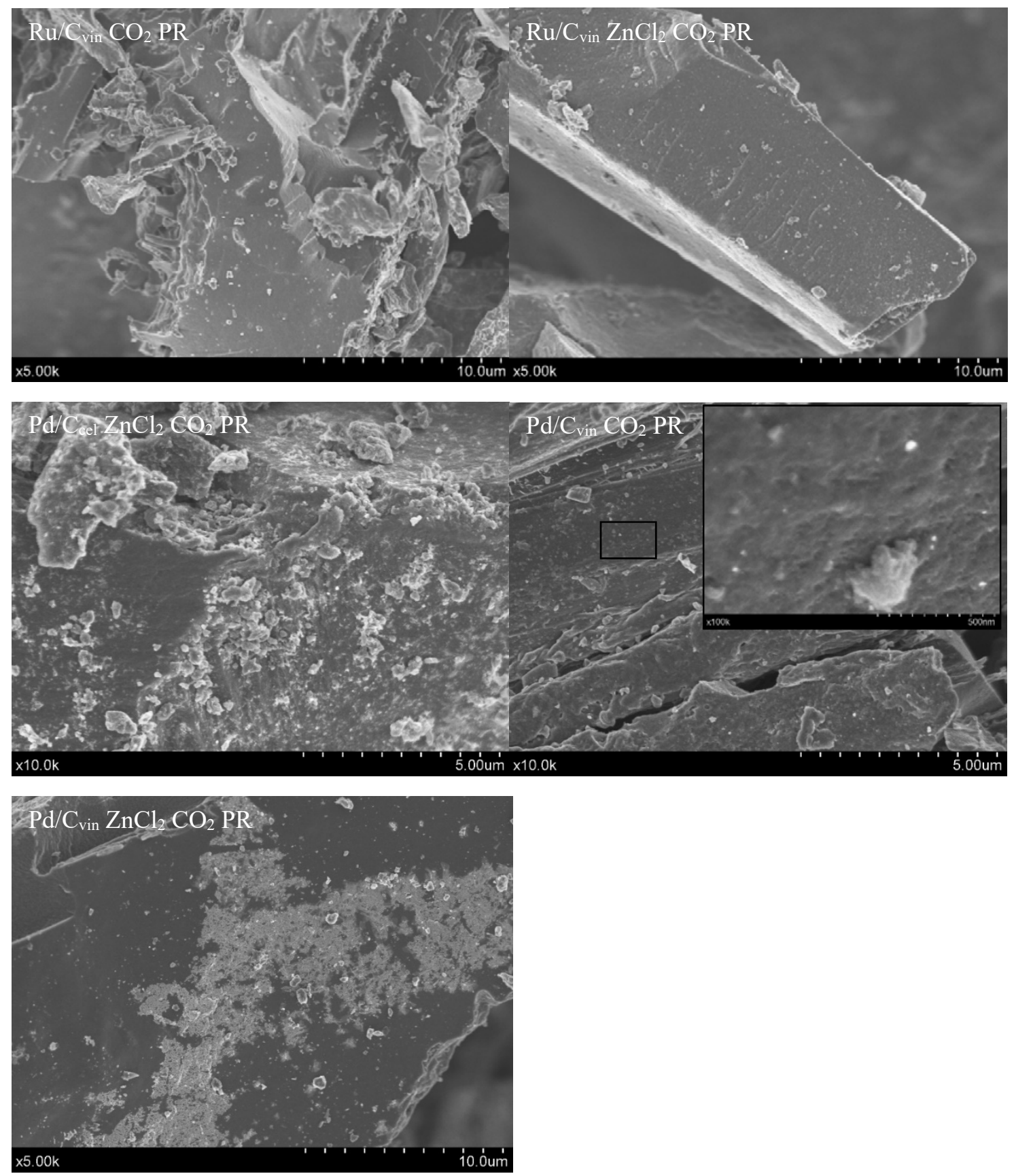

Fig. 7. Representative SEM micrographs of the spent catalysts.

Semi-quantitative composition of the spent samples was determined by EDS (Table 3), showing a lower content in the active phase than in the fresh ones, suggesting some metal leaching in the reaction media. Lixiviation is particularly evident for gold catalysts, being 
minimal or even absent in the ruthenium catalyst. Although it was not possible to quantify the palladium loading by EDS, palladium-enriched islands in the fresh catalysts synthesized onto microporous biochars [20] were absent in the spent catalyst resulting in smaller average particle sizes. A broader distribution found in the particle size histograms for the fresh samples was transformed into a narrow monomodal distribution, which could indicate indirectly a possible leaching of larger particles (21-29 nm), leaving small particles better anchored to the carbonaceous support in good agreement with the characterization results.

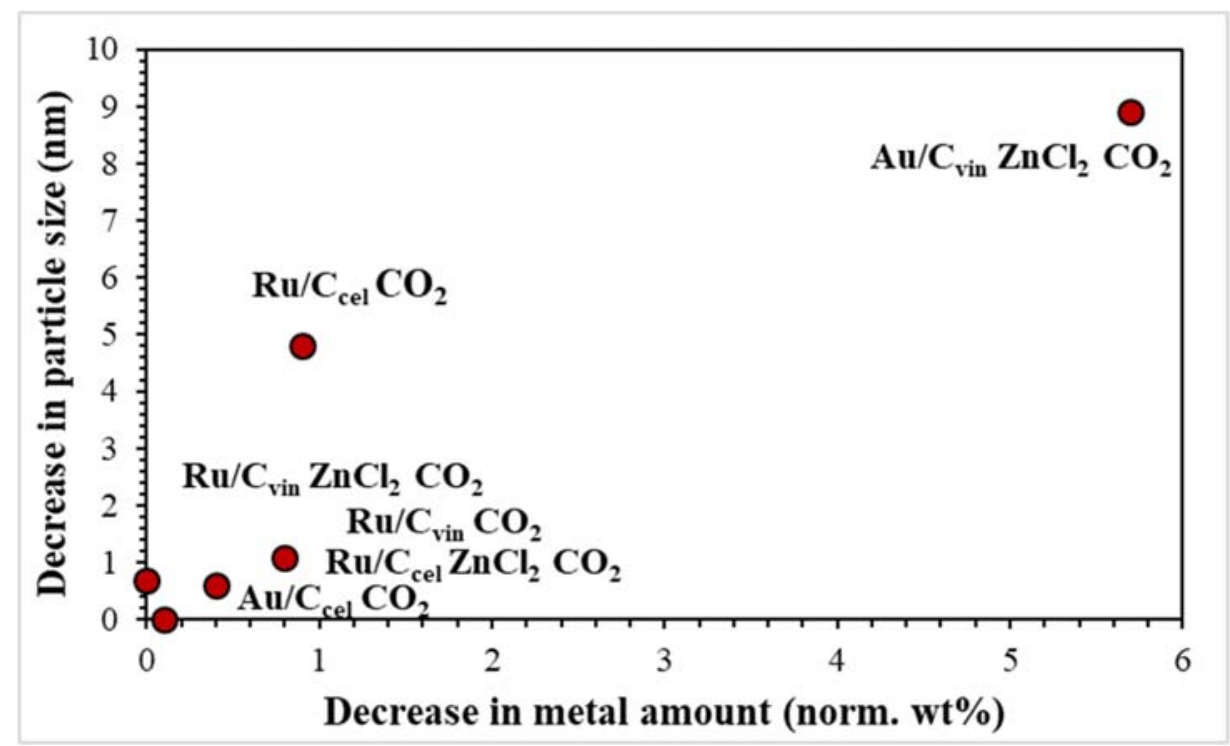

Fig. 8. Particle size vs decrease in the metal amount of the biochar catalyst.

Figure 8 shows the amount of noble metal loss after the reaction (determined from EDS analysis, (Table 3) against variation in the particle size after the reaction. Table 3 indicates a correlation between a decrease in the particle size and a loss of metal, even if this correlation is not linear. This could indicate that the major part of the leached metal is related to larger particles. 


\section{Table 3}

Semi-quantitative energy dispersive X-ray spectroscopy (EDS) results.

\begin{tabular}{|c|c|c|c|c|c|c|}
\hline $\begin{array}{c}\text { Sample } \\
\text { Fresh(*), Post } \\
\text { Reaction }\end{array}$ & $\begin{array}{l}\text { Carbon } \\
\text { [norm. } \\
\text { wt.\%] }\end{array}$ & $\begin{array}{l}\text { Oxygen } \\
\text { [norm. } \\
\text { wt. \%] }\end{array}$ & $\begin{array}{c}\text { Noble Metal } \\
\text { [norm. } \\
\text { wt.\%] }\end{array}$ & $\begin{array}{c}\mathrm{O} / \text { metal } \\
\text { ratio }\end{array}$ & $\begin{array}{c}\text { Chlorine } \\
\text { [norm. } \\
\text { wt.\%] }\end{array}$ & $\begin{array}{c}\text { Zinc } \\
\text { [norm. } \\
\text { wt.\%] }\end{array}$ \\
\hline $\mathrm{Ru} / \mathrm{C}_{\text {cel }} \mathrm{CO}_{2} \mathrm{PR}$ & $\begin{array}{c}88.7^{*} \\
83.2\end{array}$ & $8.6^{*}, 15$ & $2.7^{*}, 1.8$ & 8.3 & - & - \\
\hline $\mathrm{Ru} / \mathrm{C}_{\text {cel }} \mathrm{ZnCl}_{2} \mathrm{CO}_{2} \mathrm{PR}$ & $\begin{array}{l}78.5^{*} \\
84.3\end{array}$ & $\begin{array}{c}13.3^{*} \\
14.2\end{array}$ & $1.9^{*}, 1.5$ & 9.5 & $3.1^{*}, 0.3$ & $\begin{array}{c}3.2^{*} \\
0.5\end{array}$ \\
\hline $\mathrm{Ru} / \mathrm{C}_{\text {vin }} \mathrm{CO}_{2} \mathrm{PR}$ & $\begin{array}{c}86.2^{*} \\
72.9\end{array}$ & $\begin{array}{l}11.1^{*} \\
23.8\end{array}$ & $2.7^{*}, 1.9$ & 12.5 & - & - \\
\hline $\mathrm{Ru} / \mathrm{C}_{\mathrm{vin}} \mathrm{ZnCl}_{2} \mathrm{CO}_{2} \mathrm{PR}$ & $\begin{array}{c}80.1^{*} \\
77.7\end{array}$ & $\begin{array}{l}11.4^{*} \\
20.3\end{array}$ & $1.3^{*}, 1.3$ & 15.6 & $3.6^{*}, 0.3$ & $\begin{array}{c}3.6^{*} \\
0.4\end{array}$ \\
\hline $\mathrm{Au} / \mathrm{C}_{\text {cel }} \mathrm{CO}_{2} \mathrm{PR}$ & $\begin{array}{l}89.4^{*} \\
81.5\end{array}$ & $\begin{array}{c}10.3^{*} \\
18.3\end{array}$ & $0.3^{*}, 0.2$ & 91.5 & - & - \\
\hline $\mathrm{Au} / \mathrm{C}_{\text {cel }} \mathrm{ZnCl}_{2} \mathrm{CO}_{2} \mathrm{PR}$ & $\begin{array}{l}84^{*}, \\
\text { n.d. }\end{array}$ & $\begin{array}{c}10.2^{*} \\
\text { n.d. }\end{array}$ & $5.1^{*}$, n.d. & n.d. & $0.4^{*}$, n.d. & $\begin{array}{l}0.3^{*} \\
\text { n.d. }\end{array}$ \\
\hline $\mathrm{Au} / \mathrm{C}_{\mathrm{vin}} \mathrm{CO}_{2} \mathrm{PR}$ & $\begin{array}{c}86.5^{*} \\
79.8\end{array}$ & $\begin{array}{c}12.2^{*} \\
19.3\end{array}$ & $1.4^{*}, 0.9$ & 21.4 & - & - \\
\hline $\mathrm{Au} / \mathrm{C}_{\text {vin }} \mathrm{ZnCl}_{2} \mathrm{CO}_{2} \mathrm{PR}$ & $\begin{array}{l}73.4^{*} \\
81.4\end{array}$ & $\begin{array}{c}17.1^{*}, \\
17.2\end{array}$ & $6.8^{*}, 1.1$ & 15.6 & $1.4^{*}, 0.2$ & $\begin{array}{c}0.8^{*} \\
0.1\end{array}$ \\
\hline
\end{tabular}

Furthermore, the spent catalysts contained higher levels of oxygen, which should be correlated with the presence of oxygenated compounds on the surface, in line with DRIFTS (Figures 3 and 4). This leads to a considerable increase in the oxygen/noble metal ratio in the spent catalyst (Table 3). In addition, the residual $\mathrm{Zn}$ and $\mathrm{Cl}$ originating from the catalyst preparation procedure were partially removed during the reaction. 
The isoelectric point (IEP) of the spent solids in water are presented in Fig. 9. The fresh catalysts have more basic and less acidic character than the spent biochar catalyst. On the other hand, and according to EDS analysis by scanning electron microscopy, the ratio between oxygen to metal content also increased with increasing catalyst acidity indicating more adsorbed organic molecules on more acidic spent catalysts.

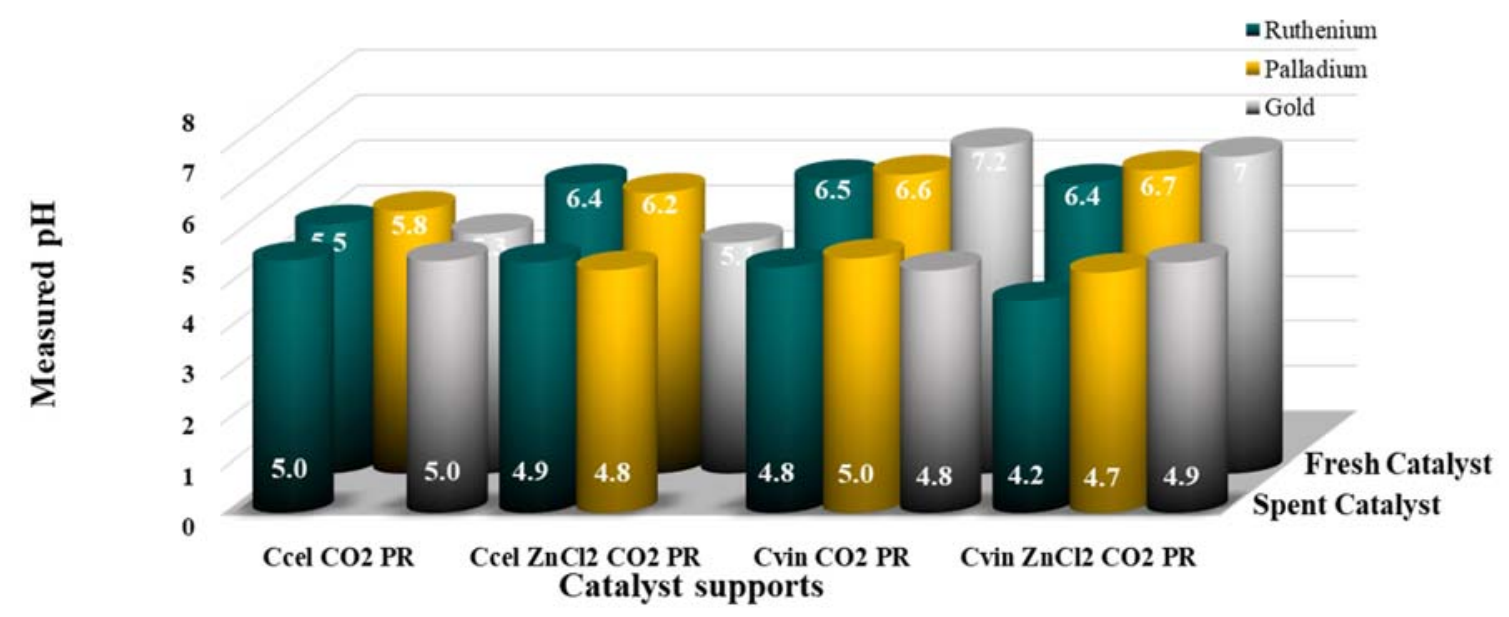

Fig. 9. a) Isoelectric point (IEP) of the spent and b) fresh catalysts.

In good agreement with DRIFTS, SEM and XRD, this increase in acidity in spent catalysts could indicate the presence of oxygenated species adsorbed on the catalyst surface being capable to be released in water lowering the $\mathrm{pH}$ of the slurry.

\subsubsection{Initial rates and conversion in $H D O$ of vanillin}

In vanillin $\mathrm{HDO}$ the initial TOF values for each catalyst calculated per mole of surface metal in the first 30 min reaction time are given in Table 4 . The results showed that with $\mathrm{Pd} / \mathrm{C}_{\text {cel }} \mathrm{CO}_{2}, \mathrm{Pd} / \mathrm{C}_{\text {vin }} \mathrm{ZnCl}_{2} \mathrm{CO}_{2}$ and $\mathrm{Ru} / \mathrm{C}_{\text {cel }} \mathrm{ZnCl}_{2} \mathrm{CO}_{2}$ the TOF values were very high and could not be even calculated accurately. For gold catalysts the TOF decreased as follows: $\mathrm{Au} / \mathrm{C}_{\text {cel }} \mathrm{CO}_{2}>\mathrm{Au} / \mathrm{C}_{\text {vin }} \mathrm{ZnCl}_{2} \mathrm{CO}_{2}>\mathrm{Au} / \mathrm{C}_{\text {vin }} \mathrm{CO}_{2}$. The latter catalysts exhibited low 
dispersion and rather large metal particles. The lowest TOF was obtained for $\mathrm{Ru} / \mathrm{C}_{\mathrm{vin}} \mathrm{ZnCl} 2$ $\mathrm{CO}_{2}$ with the metal dispersion of $36.1 \%$ corresponding to $\mathrm{Ru}$ size of $3.6 \mathrm{~nm}$. As a comparison with literature [12] the TOF was calculated for $\mathrm{Pd} / \mathrm{CN}$ catalyst giving $64 \%$ conversion of vanillin in $3 \mathrm{~h}$ at $70^{\circ} \mathrm{C}$ under 10 bar hydrogen, being $0.171 / \mathrm{s}$, which is in line with those reported in the current work in Table 4.

Vanillin was rapidly converted with all other catalysts except with $\mathrm{Au} / \mathrm{C}_{\mathrm{vin}} \mathrm{CO}_{2}$ and $\mathrm{Au} / \mathrm{C}_{\mathrm{vin}} \mathrm{ZnCl}_{2} \mathrm{CO}_{2}$. The sum of the liquid phase products determined from $\mathrm{GC}$ analysis including both reactant and products, decreased with increasing conversion. Formation of oligomers has been recently confirmed in vanillin HDO [10], in which HDO was performed in 2-propanol as a solvent at $80^{\circ} \mathrm{C}$ under 20 bar hydrogen. Such oligomer formation was demonstrated via extracting the adsorbed heavy organic compounds from the spent catalyst in heptane at its boiling point and analyzing the extract with size exclusion chromatography. The mass balance closure in the current work was the lowest for $\mathrm{Ru} / \mathrm{C}_{\text {cel }} \mathrm{ZnCl}_{2} \mathrm{CO}_{2}$ and for $\mathrm{Pd} / \mathrm{C}_{\text {vin }} \mathrm{ZnCl}_{2} \mathrm{CO}_{2}$, which were active towards hydrodeoxygenation forming rather large amounts of p-creosol. These catalysts were also quite acidic and exhibited large specific surface area due to the presence of $\mathrm{ZnCl}_{2}$ in their preparation [20].

The incomplete mass balance closure was also demonstrated by He et al. [11], who performed vanillin $\mathrm{HDO}$ over $\mathrm{Mo}_{2} \mathrm{C} / \mathrm{AC}$ under 20 bar hydrogen in water at $100^{\circ} \mathrm{C}$. 
Table 4

Catalytic results from vanillin HDO over different catalysts.

\begin{tabular}{|c|c|c|c|c|c|c|}
\hline Entry & Catalyst & $\begin{array}{c}\text { Initial vanillin } \\
\text { TOF } \\
\left(\mathrm{s}^{-1}\right)\end{array}$ & $\begin{array}{c}\text { Vanillin } \\
\text { conversion } \\
\text { after } 3 \mathrm{~h}(\%)\end{array}$ & $\begin{array}{l}\text { Liquid phase sum } \\
\text { of the masses of } \\
\text { reactant and } \\
\text { product }(\%)\end{array}$ & $\begin{array}{l}\text { Selectivity to p- } \\
\text { creosol after } 3 \mathrm{~h} \\
(\%)\end{array}$ & $\begin{array}{l}\text { Vanillyl alcohol } \\
\text { conversion at } 150 \\
\text { min*mg metal }(\%)\end{array}$ \\
\hline 1 & $\mathrm{Pd} / \mathrm{C}_{\text {cel }} \mathrm{CO}_{2}$ & Large & 99 & 96 & 18 & 18 \\
\hline 2 & $\mathrm{Pd} / \mathrm{C}_{\text {cel }} \mathrm{ZnCl}_{2} \mathrm{CO}_{2}$ & 0.12 & 99 & 75 & 54 & 22 \\
\hline 3 & $\mathrm{Pd} / \mathrm{C}_{\text {vin }} \mathrm{CO}_{2}$ & 0.36 & 100 & 89 & 18 & 6 \\
\hline 4 & $\mathrm{Pd} / \mathrm{C}_{\mathrm{vin}} \mathrm{ZnCl}_{2} \mathrm{CO}_{2}$ & Large & 100 & 68 & 92 & 78 \\
\hline 5 & $\mathrm{Ru} / \mathrm{C}_{\mathrm{cel}} \mathrm{CO}_{2}$ & 0.37 & 100 & 93 & 14 & 6 \\
\hline 6 & $\mathrm{Ru} / \mathrm{C}_{\mathrm{cel}} \mathrm{ZnCl}_{2} \mathrm{CO}_{2}$ & Large & 100 & 62 & 29 & 46 \\
\hline 7 & $\mathrm{Ru} / \mathrm{C}_{\mathrm{vin}} \mathrm{CO}_{2}$ & 0.10 & 99 & 93 & 18 & 15 \\
\hline 8 & $\mathrm{Ru} / \mathrm{C}_{\mathrm{vin}} \mathrm{ZnCl}_{2} \mathrm{CO}_{2}$ & 0.08 & 100 & 70 & 33 & 39 \\
\hline 9 & $\mathrm{Au} / \mathrm{C}_{\mathrm{cel}} \mathrm{CO}_{2}$ & 5.1 & 100 & 88 & 13 & n.d. \\
\hline 10 & $\mathrm{Au} / \mathrm{C}_{\mathrm{cel}} \mathrm{ZnCl}_{2} \mathrm{CO}_{2}$ & 0.41 & 96 & 84 & 20 & 6 \\
\hline 11 & $\mathrm{Au} / \mathrm{C}_{\mathrm{vin}} \mathrm{CO}_{2}$ & 0.37 & 77 & 79 & 21 & n.d \\
\hline 12 & $\mathrm{Au} / \mathrm{C}_{\mathrm{vin}} \mathrm{ZnCl}_{2} \mathrm{CO}_{2}$ & 1.04 & 77 & 88 & 9 & n.d. \\
\hline
\end{tabular}




\subsubsection{Product distribution and selectivity in vanillin $H D O$}

Concentration of vanillyl alcohol, which is the primary product in vanillin HDO, was plotted vs the normalized time, i.e. time multiplied by mass of the metal (Figs 10, 12 and 14), while selectivity to p-creosol as a function of vanillyl alcohol conversion is presented in Figs 11, 13 and 15. Vanillyl alcohol was rapidly formed over Pd-catalysts and further reacting to p-creosol over $\mathrm{Pd} / \mathrm{C}_{\text {cel }} \mathrm{ZnCl}_{2}$ and $\mathrm{Pd} / \mathrm{C}_{\text {vin }} \mathrm{ZnCl}_{2}$, whereas over $\mathrm{Pd} / \mathrm{C}_{\text {cel }} \mathrm{CO}_{2}$ and $\mathrm{Pd} / \mathrm{C}_{\text {vin }} \mathrm{CO}_{2}$ vanillyl alcohol transformation was nearly stopped after ca $60 \mathrm{~min} \cdot \mathrm{mg}$ Pd normalized time (Fig. 10) indicating catalyst deactivation, which exhibit large metal particle sizes and relatively low Pd dispersion [20].

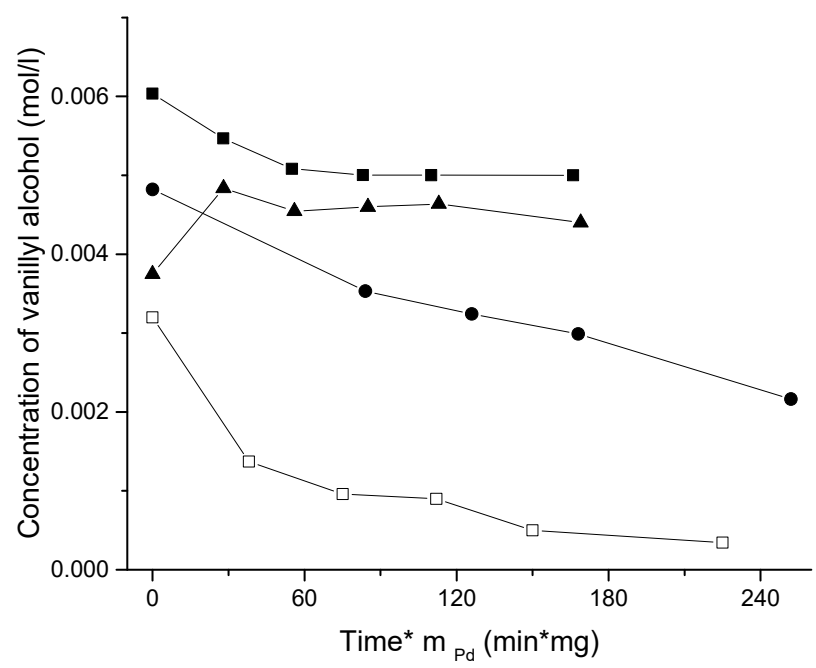

Fig. 10. Concentration of vanillyl alcohol as a function of time over $(\square) \mathrm{Pd} / \mathrm{C}_{\mathrm{vin}} \mathrm{ZnCl}_{2} \mathrm{CO}_{2}$,

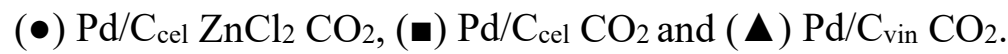




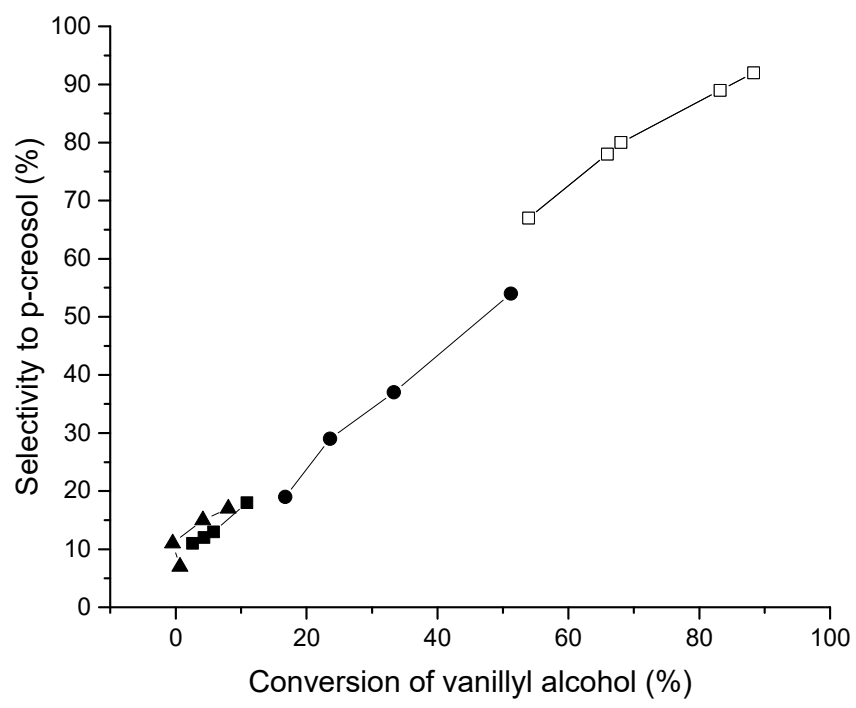

Fig. 11. Selectivity of p-creosol vs conversion of vanillyl alcohol over ( $\square) \mathrm{Pd} / \mathrm{C}_{\text {vin }} \mathrm{ZnCl} 2$ $\mathrm{CO}_{2},(\bullet) \mathrm{Pd} / \mathrm{C}_{\text {cel }} \mathrm{ZnCl}_{2} \mathrm{CO}_{2},(\boldsymbol{\bullet}) \mathrm{Pd} / \mathrm{C}_{\text {cel }} \mathrm{CO}_{2}$ and $(\boldsymbol{\Delta}) \mathrm{Pd} / \mathrm{C}_{\text {vin }} \mathrm{CO}_{2}$.

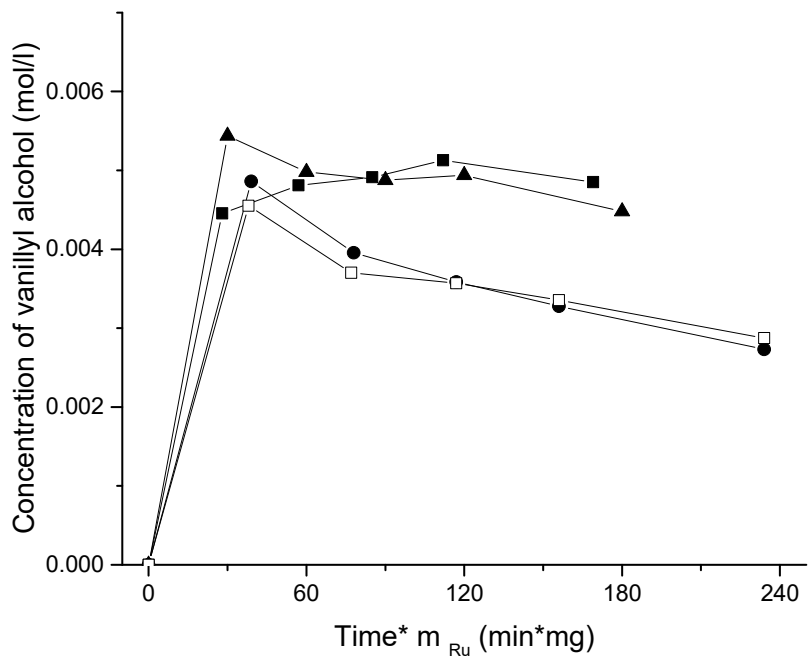

Fig. 12. Concentration of vanillyl alcohol as a function of time over ( $\square$ ) $\mathrm{Ru} / \mathrm{C}_{\mathrm{vin}} \mathrm{ZnCl}_{2} \mathrm{CO}_{2}$, $(\bullet) \mathrm{Ru} / \mathrm{C}_{\text {cel }} \mathrm{ZnCl}_{2} \mathrm{CO}_{2}$, (曰) $\mathrm{Ru} / \mathrm{C}_{\text {cel }} \mathrm{CO}_{2}$ and $(\boldsymbol{\Delta}) \mathrm{Ru} / \mathrm{C}_{\text {vin }} \mathrm{CO}_{2}$. 


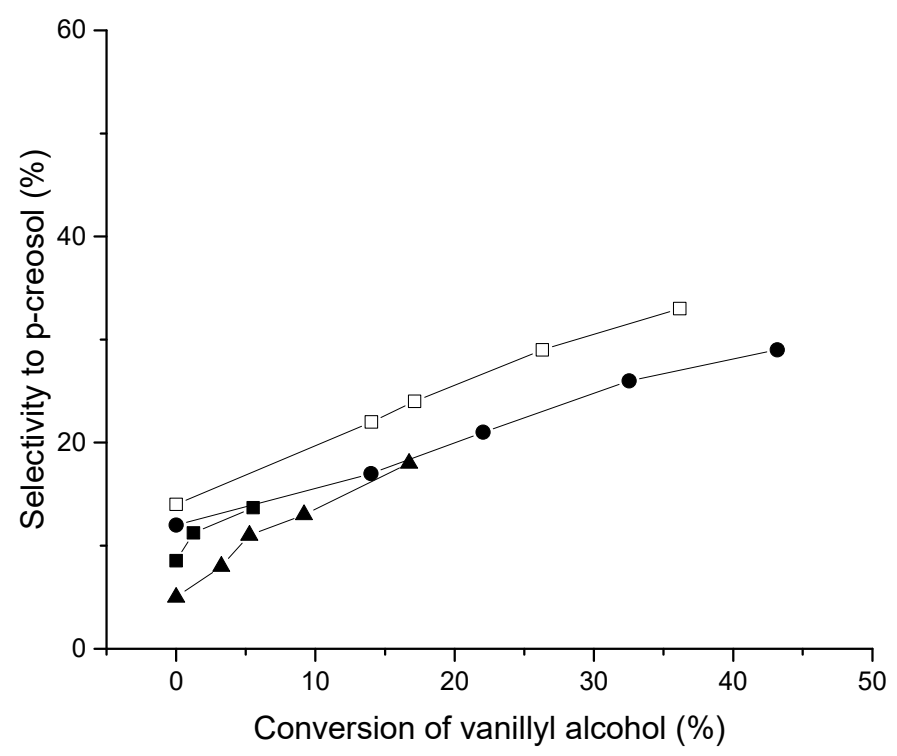

Fig. 13. Selectivity of p-creosol vs conversion of vanillyl alcohol over ( $\square$ ) $\mathrm{Ru} / \mathrm{C}_{\mathrm{vin}} \mathrm{ZnCl}_{2}$ $\mathrm{CO}_{2},(\bullet) \mathrm{Ru} / \mathrm{C}_{\text {cel }} \mathrm{ZnCl}_{2} \mathrm{CO}_{2},(\boldsymbol{\bullet}) \mathrm{Ru} / \mathrm{C}_{\text {cel }} \mathrm{CO}_{2}$ and $(\boldsymbol{\Delta}) \mathrm{Ru} / \mathrm{C}_{\text {vin }} \mathrm{CO}_{2}$.

For $\mathrm{Ru}$ supported catalysts an analogous trend was observed, namely the most active catalysts were $\mathrm{Ru} / \mathrm{C}_{\text {vin }} \mathrm{ZnCl}_{2} \mathrm{CO}_{2}$ and $\mathrm{Ru} / \mathrm{C}_{\text {cel }} \mathrm{ZnCl}_{2} \mathrm{CO}_{2}$ (Fig. 13). [20]. $\mathrm{Ru} / \mathrm{C}_{\text {cel }} \mathrm{CO}_{2}$ gave the lowest conversion of vanillyl alcohol to p-creosol due to its large metal particle size [20]. The three supported gold catalysts (Fig. 14) were not active in transforming vanillyl alcohol to $\mathrm{p}$-creosol, while $\mathrm{Au} / \mathrm{C}_{\text {cel }} \mathrm{ZnCl}_{2}$ showed a minor reaction of vanillyl alcohol further to $\mathrm{p}$ creosol. The Au particle sizes for four different Au supported catalysts vary in the range of $7.7-24.7 \mathrm{~nm}$. 


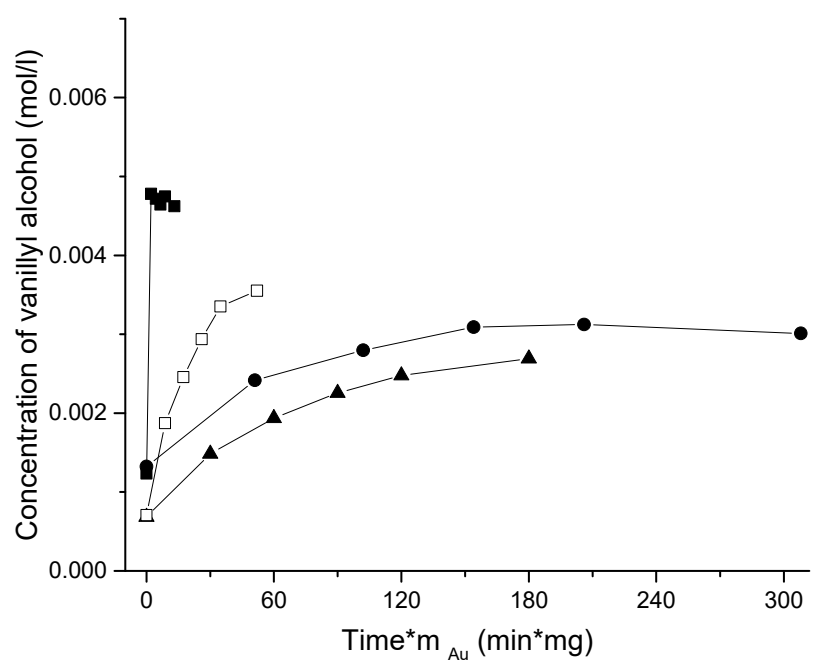

Fig. 14. Concentration of vanillyl alcohol as a function of time over ( $\square$ ) $\mathrm{Au} / \mathrm{C}_{\mathrm{vin}} \mathrm{ZnCl}_{2} \mathrm{CO}_{2}$, $(\bullet) \mathrm{Au} / \mathrm{C}_{\text {cel }} \mathrm{ZnCl}_{2} \mathrm{CO}_{2},(\boldsymbol{\bullet}) \mathrm{Au} / \mathrm{C}_{\text {cel }} \mathrm{CO}_{2}$ and $(\boldsymbol{\Delta}) \mathrm{Au} / \mathrm{C}_{\text {vin }} \mathrm{CO}_{2}$.

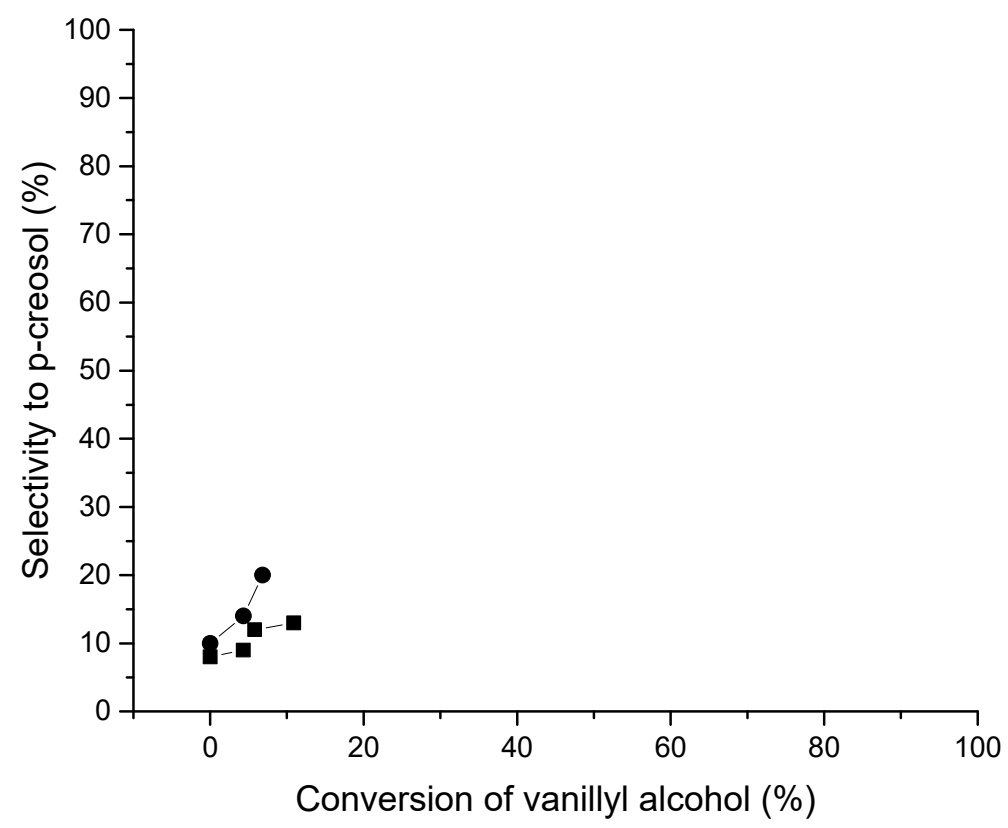

Fig. 15. Selectivity of $\mathrm{p}$-creosol vs conversion of vanillyl alcohol over $(\bullet) \mathrm{Au} / \mathrm{C}_{\text {cel }} \mathrm{ZnCl} 2$ $\mathrm{CO}_{2}$ and $(\boldsymbol{\square}) \mathrm{Au} / \mathrm{C}_{\text {cel }} \mathrm{CO}_{2}$. With the two other Au catalysts, $\mathrm{Au} / \mathrm{C}_{\text {vin }} \mathrm{ZnCl}_{2} \mathrm{CO}_{2}$ and $\mathrm{Au} / \mathrm{C}_{\mathrm{vin}}$ $\mathrm{CO}_{2}$ no maximum in vanillyl alcohol was obtained due to slow reaction. 
In order to correlate these results better with catalyst properties, vanillyl alcohol conversion, calculated from its highest concentration at a constant normalized time, 150 min $\cdot$ mass of metal, was plotted against the metal dispersion and total acidity (Fig. 16).
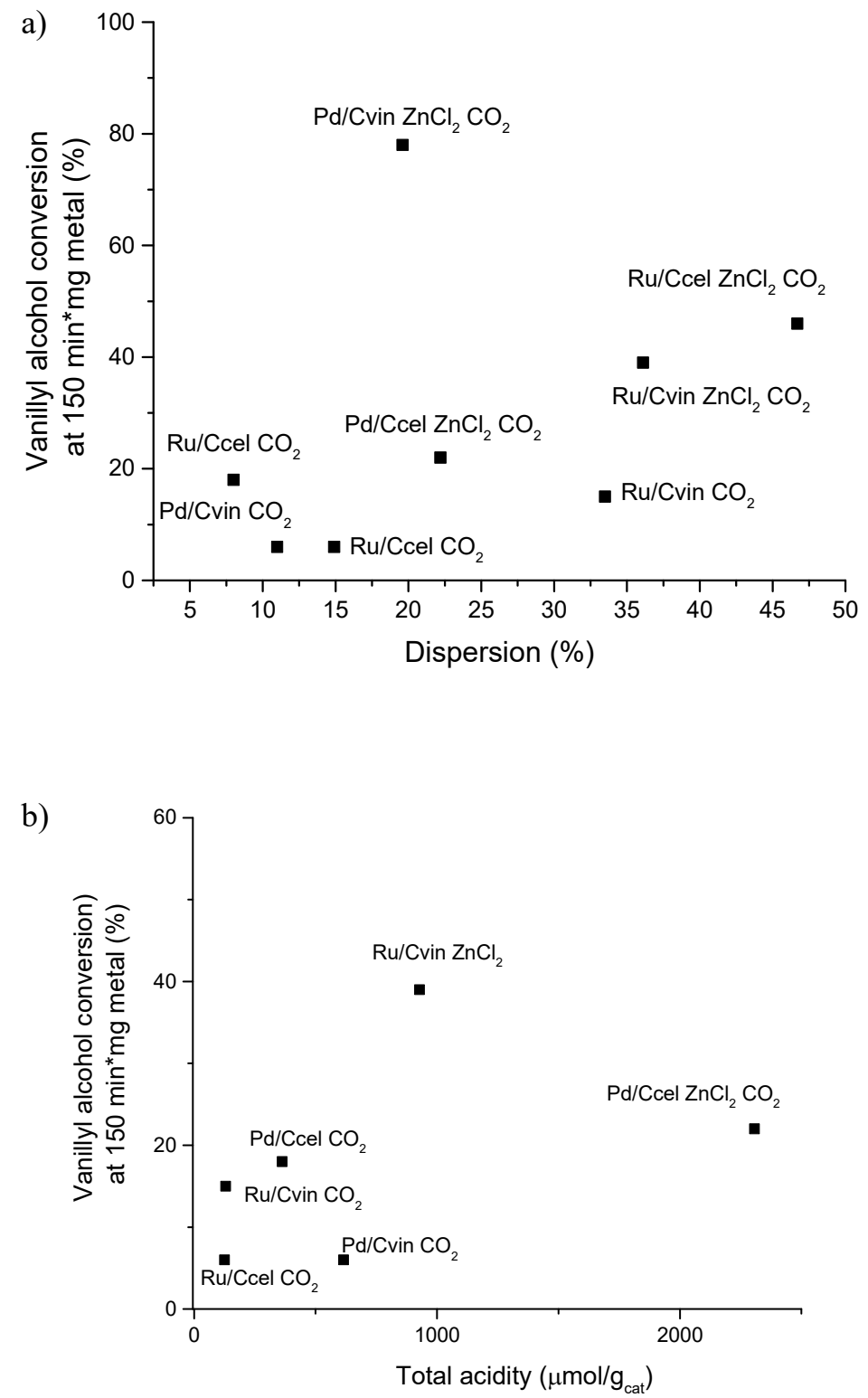

Fig. 16. Vanillyl alcohol conversion at the normalized time $150 \mathrm{~min} * \mathrm{mg}$ metal as a function of a) metal dispersion and b) total acidity of the catalyst. 
It can be seen from Fig. 16 that although vanillyl alcohol conversion was slightly increasing with increasing metal dispersion, a clear correlation between vanillyl alcohol formation and metal dispersion cannot be seen. The highest vanillyl alcohol conversion was obtained with $\mathrm{Pd} / \mathrm{C}_{\mathrm{vin}} \mathrm{ZnCl}_{2} \mathrm{CO}_{2}$ exhibiting ca. $20 \%$ dispersion showing that a moderate metal dispersion is required for high hydrodeoxygenation activity. When comparing the effect of metal dispersion on vanillin HDO, it can be seen from [11] that with two $\mathrm{Pd} / \mathrm{CN}$ catalysts having metal dispersion of $21 \%$ and $48 \%$, gave yields of p-creosol $23 \%$ and $45 \%$ showing analogously to this work that higher metal dispersion is beneficial for HDO of vanillin.

Catalyst acidity is important for formation of p-creosol, as it occurs via dehydration of vanillyl alcohol, catalysed by acid sites, followed by hydrogenation of the formed alkene, which proceeds on metal sites [41]. Acid groups act as $\mathrm{H}$ donors and their presence results in an evident increase of the catalytic activity. In fact, hydrodeoxygenation using $\mathrm{H}$ donors, such as alcohols, or formic acid, has been considered as an interesting alternative to use of external $\mathrm{H}_{2}[42,43]$. In this sense, the presence of hydroxyl groups on the carbon support surface can also favor HDO activity, since these groups act as Bronsted acid sites and were described as having a key role in $\mathrm{C}-\mathrm{O}$ activation via a proton transfer to the $\mathrm{O}$ atom [44], and also in HDS processes [45].

Among the studied catalysts the most active for hydrodeoxygenation are $\mathrm{Pd} / \mathrm{C}_{\mathrm{vin}}$ $\mathrm{ZnCl}_{2} \mathrm{CO}_{2}, \mathrm{Ru} / \mathrm{C}_{\text {cel }} \mathrm{ZnCl}_{2} \mathrm{CO}_{2}$ and $\mathrm{Ru} / \mathrm{C}_{\text {vin }} \mathrm{ZnCl}_{2} \mathrm{CO}_{2}$. These catalysts exhibited also a very high specific surface area and large pore diameter in the range of $3.31-3.36 \mathrm{~nm}$. The lowest acidity was observed to metal catalysts supported on $\mathrm{C}_{\text {cel }} \mathrm{CO}_{2}$ according to [19] and among these three catalysts, $\mathrm{Ru} / \mathrm{C}_{\text {cel }} \mathrm{CO}_{2}$ and $\mathrm{Pd} / \mathrm{C}_{\text {cel }} \mathrm{CO}_{2}$ exhibited large metal particle sizes and 
they were not very active in hydrodeoxygenation of vanillin. These results are opposite to [14], in which a more acidic catalyst, such as Pd supported on amine-functionalized metal organic framework, $\mathrm{NH}_{2}-\mathrm{UiO}-66$ containing $\mathrm{Zr}$ sites exhibited Lewis acidity and was very active in producing $100 \%$ yield of p-creosol at $90{ }^{\circ} \mathrm{C}$ under 5 bar hydrogen. In the current case it can be concluded that the most decisive parameter for vanillin HDO is high metal dispersion and the specific properties of the metal. It is also known that Pd in the presence of hydrogen has Brønsted acidity, has been shown in [40]. With the best catalyst, $\mathrm{Pd} / \mathrm{C}_{\mathrm{vin}} \mathrm{ZnCl}$ $\mathrm{CO}_{2}$, selectivity among the liquid phase products to p-creosol was $92 \%$ at complete vanillin conversion (Fig. 11) corresponding to the p-creosol yield of $68 \%$ due to an incomplete mass balance closure. The results with $\mathrm{Pd} / \mathrm{C}_{\text {vin }} \mathrm{ZnCl}_{2} \mathrm{CO}_{2}$ are nearly as good as the ones obtained with $\mathrm{Pd} / \mathrm{C}$ supported on commercial $\mathrm{C}_{\mathrm{darco}}$ [9], although acidity of the former catalyst is much higher than that for $\mathrm{Pd} / \mathrm{C}_{\text {darco. }}$. The dispersions of $\mathrm{Pd} / \mathrm{C}_{\text {vin }} \mathrm{ZnCl}_{2} \mathrm{CO}_{2}$ and $\mathrm{Pd} / \mathrm{C}_{\text {darco }}$ are $19.6 \%$ and $33.5 \%$ [16], respectively, indicating that a relatively high dispersion is needed.

The mesoporous support was also reported to be advantageous in vanillin HDO in [11], when a mesoporous carbon-nitride supported Pd nanocatalyst was utilized giving a nearly quantitative yield to $\mathrm{p}$-creosol at $70^{\circ} \mathrm{C}$ in water after 30 min under 30 bar hydrogen nearly quantitative yield to p-creosol. Palladium supported on mesoporous silica was also efficient in vanillin HDO in methanol as a solvent in a down-flow fixed bed reactor giving at $300^{\circ} \mathrm{C}$ after $6 \mathrm{~h} 88 \%$ selectivity towards p-cresol [46], which is the product formed via demethoxylation of p-creosol. p-Cresol was not found in the current work. On the other hand, Ru supported on microporous HZSM-5 gave high carbon balance and methylcyclohexane as the main product in vanillin $\mathrm{HDO}$ at $170^{\circ} \mathrm{C}$ under 40 bar hydrogen [18] indicating that mesoporous catalysts are not necessary required. 
Selectivity to p-creosol was plotted as a function of vanillyl alcohol conversion showing that it is increasing linearly with increasing vanillyl alcohol conversion (Figs 13$15)$.

\subsubsection{Kinetic modelling of vanillin $H D O$}

Kinetic modelling of vanillin HDO was developed for the following reaction network:

$$
\begin{aligned}
& V \stackrel{1}{\longrightarrow} \mathrm{VOH} \stackrel{2}{\longrightarrow} \mathrm{C} \\
& V \stackrel{3}{\rightleftarrows} U
\end{aligned}
$$

Eq. (3) contains only a part of the overall network. $V, V O H$ and $C$ denote vanillin, vanillyl alcohol and p-creosol. Vanillin can, however, be reversible transformed to either oligomers and adsorbed on the catalyst surface reacting further to unknown compounds $U$. This network explains selectivity dependence on conversion (Fig. 13-15) by the reaction of vanillyl alcohol to p-creosol and an incomplete the liquid phase mass balance closure by considering a rapid vanillin disappearance prior to formation of the reaction products in the liquid phase visible in HPLC.

Considering the catalyst bulk concentration, $\rho_{B}$, defined as: $\rho_{B}=m_{\text {cat }} / \mathrm{Vol}$, the following equations were used for each individual reaction rate, $r_{i}$ :

$$
\begin{aligned}
& r_{1}=\rho_{B} \cdot \frac{k_{1} \cdot C_{V}}{1+K_{a d} \cdot C_{V}} \\
& r_{2}=\rho_{B} \cdot \frac{k_{2} \cdot C_{V O H}}{1+K_{a d} \cdot C_{V}}
\end{aligned}
$$




$$
\begin{aligned}
& r_{3}=\rho_{B} \cdot \frac{k_{3} \cdot C_{V}}{1+K_{a d} \cdot C_{V}} \\
& r_{4}=\rho_{B} \cdot \frac{k_{4} \cdot C_{U}}{1+K_{a d} \cdot C_{V}}
\end{aligned}
$$

where $k_{i}$ and $c_{i}$ are respectively rate constants and concentrations. Form the above equations, the mass balance for each compound are given by the following expressions:

$$
\begin{aligned}
& \frac{d C_{V}}{d t}=-r_{1}-r_{3}+r_{4}=\rho_{B} \cdot \frac{-\left(k_{1}+k_{3}\right) \cdot C_{V}+k_{4} \cdot C_{U}}{1+K_{a d} \cdot C_{V}} \\
& \frac{d C_{V O H}}{d t}=r_{1}-r_{2}=\rho_{B} \cdot \frac{k_{1} \cdot C_{V}-k_{2} \cdot C_{V O H}}{1+K_{a d} \cdot C_{V}} \\
& \frac{d C_{C}}{d t}=r_{2}=\rho_{B} \cdot \frac{k_{2} \cdot C_{V O H}}{1+K_{a d} \cdot C_{V}} \\
& \frac{d C_{U}}{d t}=r_{3}-r_{4}=\rho_{B} \cdot \frac{k_{3} \cdot\left(C_{V}-\frac{C_{U}}{K_{e q}}\right)}{\left(1+K_{a d} \cdot C_{V}\right)} ; \quad K_{e q}=\frac{k_{3}}{k_{4}}
\end{aligned}
$$

were $K_{e q}$ is the equilibrium constant of step 3 in eq. (4).

The parameter estimation was performed with the Levenberg-Marguardt method incorporated in the parameter optimization Modest software [47]. The objective function minimized was the sum of squared residuals, calculated as:

$$
\theta=\sum\left(y_{i}-\hat{y}_{i}\right)^{2}
$$

where the terms " $y_{i}$ " and " $\hat{y}_{i}$ " are the experimental and calculated values respectively. The coefficient of correlation $R^{2}$ was calculated as:

$$
R^{2}=1-\frac{\sum\left(y_{i}-\hat{y}_{i}\right)^{2}}{\sum\left(y_{i}-\bar{y}_{i}\right)^{2}}
$$


with $\overline{y_{i}}$ denoting the average value of all the experimental observations.

The results of model fittings are shown in Fig.16, whereas the values of kinetic parameters are presented in Table 5. In all the cases the parameter $k_{4}$ was found to be negligible. Figure 16 clearly illustrates that the kinetic model is capable of explaining satisfactorily the experimental observations, being a strong argument in favour of the proposed reaction network. Thus, the upper performance of $\mathrm{Pd} / \mathrm{C}_{\mathrm{vin}} \mathrm{ZnCl}_{2} \mathrm{CO}_{2}$ catalyst in vanillin conversion, and in selectivity to p-cresol formation is given by their larger values of the $k_{1}$ kinetic constant and of the ratio $k_{3} / k_{1}$ obtained with this sample. The $k_{3} / k_{1}$ ratio gives a quantitative idea of the intrinsic selectivity to the formation of p-creosol. The obtained values of this ratio for the three catalysts are: $0.385(\mathrm{Ru}), 0.333(\mathrm{Au})$ and $0.638(\mathrm{Pd})$, which confirm the trends shown on Figures 11 to 15.

a)

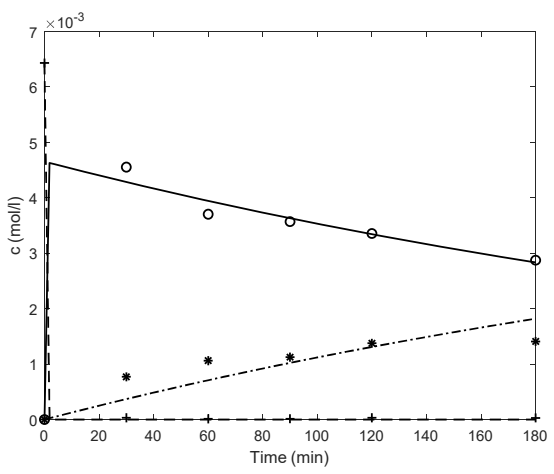

b)

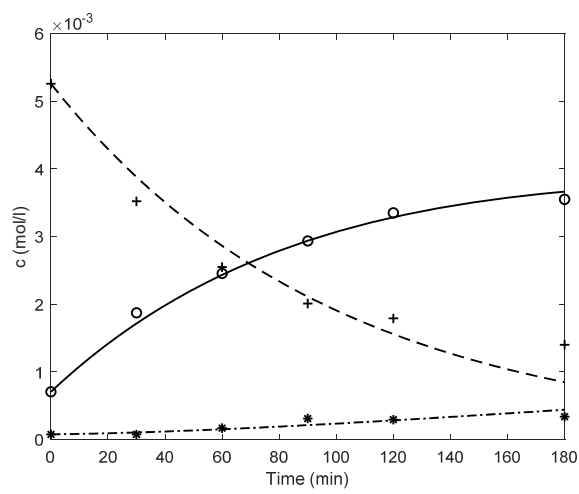

c)

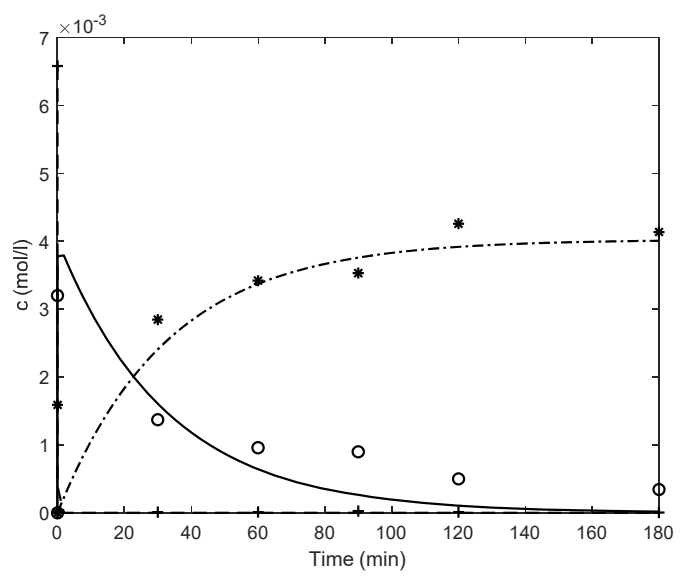


Fig. 17. Comparison of experimental and calculated values for vanillin $H D O$ over: $a) \mathrm{Ru} / \mathrm{C}_{\mathrm{vin}}$ $\mathrm{ZnCl}_{2} \mathrm{CO}_{2}$; b) $\mathrm{Au} / \mathrm{C}_{\text {vin }} \mathrm{ZnCl}_{2} \mathrm{CO}_{2}$; and $\left.c\right) \mathrm{Pd} / \mathrm{C}_{\text {vin }} \mathrm{ZnCl}_{2} \mathrm{CO}_{2}$. Notation: vanillin (+), vanillyl alcohol (o) and p-creosol (*).

Table 5.

Calculated kinetic parameters for HDO of vanillin with the studied catalysts.

a) $\mathrm{Ru} / \mathrm{C}_{\mathrm{vin}} \mathrm{ZnCl}_{2} \mathrm{CO}_{2} ; \mathrm{R}^{2}=98.28 \%$

\begin{tabular}{cccc}
\hline Parameter & Value & Standard error & Relative standard error (\%) \\
\hline$k_{1}$ & 5.71 & 0.64 & 11.2 \\
$k_{2}$ & $0.27 \cdot 10^{-3}$ & $0.02 \cdot 10^{-3}$ & 8.3 \\
$k_{3}$ & 2.2 & 0.36 & 16.5 \\
$K_{a d}$ & 0.157 & 0.045 & 28.9 \\
\hline
\end{tabular}

b) $\mathrm{Au} / \mathrm{C}_{\mathrm{vin}} \mathrm{ZnCl}_{2} \mathrm{CO}_{2} ; \mathrm{R}^{2}=97.15 \%$

\begin{tabular}{cccc}
\hline Parameter & Value & Standard error & Relative standard error (\%) \\
\hline$k_{1}$ & 0.015 & $0.28 \cdot 10^{-2}$ & 18.0 \\
$k_{2}$ & $0.15 \cdot 10^{-2}$ & $0.74 \cdot 10^{-3}$ & 48.9 \\
$k_{3}$ & $0.5 \cdot 10^{-2}$ & $0.15 \cdot 10^{-2}$ & 29.2 \\
$K_{a d}$ & $0.1 \cdot 10^{-5}$ & 48 & large \\
\hline
\end{tabular}


c) $\mathrm{Pd} / \mathrm{C}_{\text {vin }} \mathrm{ZnCl}_{2} \mathrm{CO}_{2} ; \mathrm{R}^{2}=90.32 \%$

\begin{tabular}{cccc}
\hline Parameter & Value & Standard error & Relative standard error (\%) \\
\hline$k_{1}$ & 367 & 55 & 15.0 \\
$k_{2}$ & 0.06 & $0.94 \cdot 10^{-2}$ & 16.3 \\
$k_{3}$ & 234 & 26.6 & 8.8 \\
$K_{a d}$ & 49 & 3.1 & 16.0 \\
\hline
\end{tabular}

\section{Conclusions}

Hydrodeoxygenation of vanillin was investigated over noble metal ( $\mathrm{Au}, \mathrm{Pd}, \mathrm{Ru})$ supported active carbon catalysts in water at $100{ }^{\circ} \mathrm{C}$ under 30 bar hydrogen. The support was prepared via pyrolysis under $\mathrm{CO}_{2}$ atmosphere using either cellulose or wine waste as a raw material. As a comparison the support was also prepared using a chemical activation with $\mathrm{ZnCl}_{2}$ and $\mathrm{HNO}_{3}$ treatment to enhance the specific surface area and to demineralize it.

HR-TEM results of the spent catalysts revealed that re-dispersion of especially large $\mathrm{Ru}$ - and Pd-particles on active carbon occurred. Metal leaching determined by ICP showed that it was more prominent for the catalysts with large metal particle sizes.

Hydrodeoxygenation of vanillyl in water at $100^{\circ} \mathrm{C}$ under 30 bar hydrogen over metal supported active carbon catalysts resulted in partial hydrodeoxygenation of vanillin producing p-creosol. The highest selectivity to $\mathrm{p}$-creosol, $92 \%$ at complete vanillin conversion was obtained with $\mathrm{Pd} / \mathrm{C}$ catalyst prepared via pyrolysis under $\mathrm{CO}_{2}$ from wine waste and using $\mathrm{ZnCl}_{2}$ as a chemical activation agent. The hydrodeoxygenation was promoted by high metal dispersion. 
Kinetic modelling, including the rapid and reversible adsorption of vanillin on the catalyst surface, was successfully performed giving adequate estimated concentrations of reactant and products with the degree of explanation varying in the range of $90-98 \%$.

\section{Acknowledgments}

Financial support for this work has been obtained from the Spanish Ministerio de Economía y Competitividad (MINECO) (Grants ENE2013-47880-C3-2-R, ENE2017-82451-C3-3-R and ENE2017-82451-C3-1-R) co-financed by FEDER funds from the European Union. J.L. Santos also acknowledges the MINECO for his pre-doctoral fellowship (BES-2014-068244) and the mobility fellowship (EEBB-I-17-11979). 


\section{References}

[1] P. Mäki-Arvela, D. Yu. Murzin, Catalysts, 7 (2017) 265, 1-40.

[2] W. Jin, L. Pastor-Pérez, D. Shen, A. Sepuldéva-Escribano, S. Gu, T. Ramirez-Reina, ChemCatCherm, 11 (2019) 924-960.

[3] A. L. Jongerius, R. W. Gosselink, J. Djikstra, J.H. Bitter, P. C.-A. Bruijnincx, B. M: Weckhuysen, ChemCatChem 5 (2013) 2964-2972.

[4] Q. Lu, C.-J. Chen, W. Luc, J. G. Chen, A. Bhan, F. Jiao, ACS Catal. 6 (2016) 3506-3514.

[5] Q. Tan, G. Wang, A. Long, A. Dinse, C. Buda, J. Shabaker, D. E. Resasco, J. Catal. 347 (2017) 102-115.

[6] A. Berenguer, J. A. Bennett, J. Hunns, I. Moreno, J. M. Coronado, A. F. Lee, P. Pizarro, K. Wilson, D. P. Serrano, Catal. Today 304 (2019) 72-79.

[7] T. H. Parsell, B. C. Owen, I. Klein, T. M. Jamell, C. L. Marcum, L. J. Haupert, L. M. Amundson, H. I. Kenttämaa, F. Ribeiro, J. T. Miller, M. M. Abu-Omar, Chem. Sci. 4 (2013) 806-813.

[8] A. B. Bindwal, P. D. Vaidya, Energy Fuels 28 (2014) 3357-3362.

[9] J. L. Santos, M. Alda-Onggar, V. Fedorov, M. Peurla, K. Eränen, P. Mäki-Arvela, M.Á. Centeno, D. Yu. Murzin, Appl.Catal. A, Gen. 561 (2018) 137-149.

[10] A. Sulman, P. Mäki-Arvela, L. Bomont, V. Fedorov, M. Alda-Onggar, A. Smeds, J. Hemming, V. Russo, J. Wärnå, M. Käldström, D. Yu. Murzin, Catal. Lett. 148 (2018) 2856-2868.

[11] L. He, Y. Qin, H. Lou, P. Chen, RSC Adv. 5 (2015) 43141-43147.

[12] H. Jiang, X. Yu, X. Peng, N. Zhang, R. Nie, X. Lu, D. Zhou, Q. Xia, RSC Adv. 6 (2016) 69045-69051. 
[13] R. Nie, H. Yang, H. Zhang, X. Yu, X. Lu, D. Zhou, Q. Xia, Green Chem. 19 (2017) 3126-3134.

[14] X. Xu, Y. Gong, P. Zhang, H. Li, Y. Wang, J. Am. Chem. Soc. 134 (2012) 16987-16990.

[15] F. Zhang, S. Zheng, Q. Xiao, Y. Zhong, W. Zhu, A. Lin, M. S. El-Shall, Green Chem. 18 (2016) 2900-2908.

[16] Z. Zhu, H. Tan, J. Wang, S. Yu, K. Zhou, Green Chem. 16 (2014) 2636-2643.

[17] X. Yang, Y. Liang, Y. Cheng, W. Song, X. Wang, Z. Wang, J. Qiu, Catal. Comm. 47 (2014) 28-31.

[18] X. Yang, X., Y. Liang, X. Zhao, Y. Song, L. Hu, X. Wang, Z. Wang, J. Qiu, RSC Adv. 4 (2014) 31932-31936.

[19] L. Wang, J. Zhang, X. Xi, A. Zheng, F. Deng, C. Chen, Y. Ji, F. Liu, X. Meng, F.-S. Xiao, ACS Catal. 5 (2015) 2727-2734.

[20] J. L. Santos, P. Mäki-Arvela, A, Monzón, D. Yu. Murzin, M. A. Centeno, Metal catalysts supported on biochars: Part I Synthesis and characterization, submitted 2019.

[21] Q. Li, Q. Tao, C. Yuan, Y. Zheng, G. Zhang, J. Liu, Int. J Heat Mass Trans. 120 (2018) $1162-1172$.

[22] H. Takagi, K. Maruyama, N. Yoshizawa, Y. Yamada, Y. Sato, Fuel 83 (2004) 24272433.

[23] Y.F. Han, Z. Zhong, K. Ramesh, F. Chen, L. Chen, J. Phys. Chem. C 111 (2007) 31633170.

[24] H. Markus, P. Mäki-Arvela, N. Kumar, N.V. Kulkova, P. Eklund, R. Sjöholm, B. Holmbom, T. Salmi, D. Yu Murzin, Catal. Lett. 103 (2005) 1-2.

[25] C. Risner, M. Kiser, J. Sci. Food Agric. (2008) 1423-1430.

[26] X. Lan, E. J.M. Hensen, T. Weber, Appl. Catal. A, Gen. 550 (2018) 57-66. 
[27] T. Cordero-Lanzac, R. Palos, I. Hita, J. M. Arandes, J. Rodríguez-Mirasol, T. Cordero, J. Bilbao, P. Castaño, Appl. Catal. B: Env. 239 (2018) 513-524.

[28] Z. Q. Li, C. J. Lu, Z. P. Xia, Y. Zhou, Z. Luo. Carbon 45 (2007) 1686-1695.

[29] I. Hachemi, N. Kumar, P. Mäki-Arvela, J. Roine, M. Peurla, J. Hemming, J. Salonen, D. Yu. Murzin. J. Catal. 347 (2017) 205-221.

[30] F. Romero-Sarria, J. J. Plata, O. H. Laguna, A. M. Márquez, M. A. Centeno, J. Fdez Sanz, J. A. Odriozola, RSC Adv. 4 (2014), 13145-13152.

[31] T. Shimizu, T. Teranishi, S. Hasegawa, M. Miyake. J. Phys. Chem. B 107 (2003) 27192724.

[32] H. Lee, H. Kim, M. J. Yu, C. H. Ko, J. K. Jeon, J. Jae, S. H. Park, S. C. Jung, Y. K. Park. Sci. Rep. 6, 28765.

[33] C. Newman, X. Zhou, B. Goundie, I. T. Ghampson, R. A. Pollock, Z. Ross, M. C. Wheeler, R. W. Meulenberg, R. N. Austin, B. G. Frederick, Appl. Catal. A: Gen. 477 (2014) 64-74.

[34] A.-R. Rautio, P. Mäki-Arvela, M. Huuhtanen, R. Keiski, K. Kordas, RSC Adv. 5 (2015) 49487-49492.

[35] G. Viau, R. Brayner, L. Poul, N. Chakroune, E. Lakaze, F. Fièvet-Vincent, F. Fièvet, Chem. Mater. 15 (2003) 486-494.

[36] C.H. Bartholomew, R.J. Farrauto, Fundamentals of Industrial Catalytic Processes, second ed., Wiley-Interscience, Hoboken, USA, 2006.

[37] J. D. López-González, F. Martínez-Vilchez, F. Rodríguez-Reinoso. Carbon 18 (1980) 413-418.

[38] W. Y. Hernández, F. Romero-Sarria, M. A. Centeno, J.A. Odriozola, J. Phys. Chem. C $114(2010)$ 10857-10865 
[39] F. Romero-Sarria, L. M. Martínez T., M. A. Centeno, J. A. Odriozola J. Phys. Chem. C 111 (2007) 14469-14475.

[40] G.C. Torres, E.L. Jablonski, G.T. Baronetti, A.A. Castro, S.R. De Miguel, O.A. Scelza, M.D. Blanco, M.A. Pena-Jiménez, J.L.G. Fierro. Appl. Catal. A: Gen. 161 (1997) 213260.

[41] D.Yu. Murzin, S.R. Konuspaev, Kinet. Catal., 33 (1992) 540-548.

[42] T. Guo, Q. Xia, Y. Shao, X. Liu, Y. Wang, Appl. Catal. A: Gen. 547 (2017) 30-36.

[43] X. Wang, R. Rinaldi, Angew. Chem. 52 (2013) 11499-11503.

[44] G. T. Kasun Kalhara Gunasooriya, Alexander P. van Bavel, Herman P. C. E. Kuipers, Mark Saeys, ACS Catal., 6 (2016) 3660-3664.

[45] T.-R.Viljava, A.O.I. Krause, Studies in Surface Science and Catalysis, 106 (1997) 343352.

[46] C. D. Baertsch, K. T. Komla, Y.-H. Chua, E. Iglesia, J. Catal. 205 (2002) 44-57.

[47] H. Haario, Modest users guide, Profmath Oy, Helsinki, 2007. 
Supporting Info

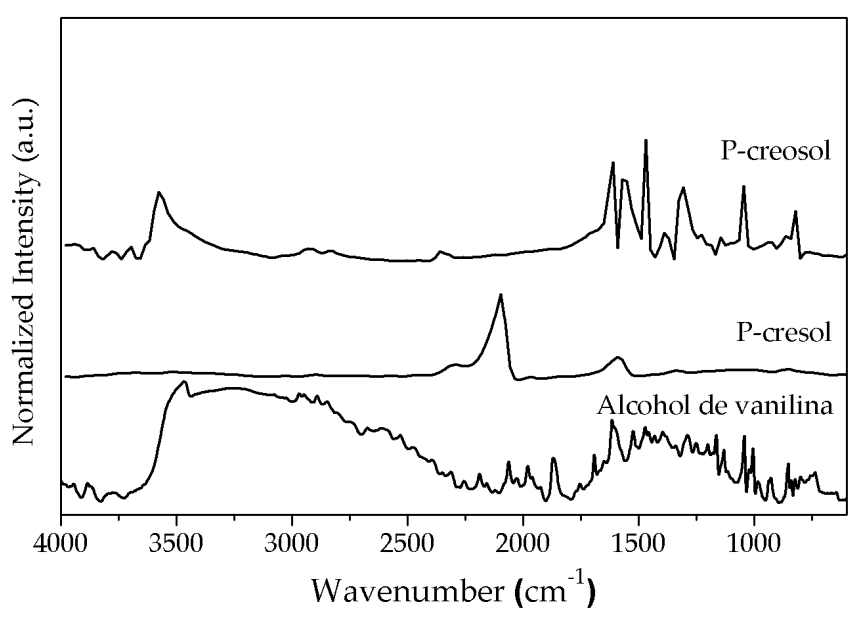

Fig. S1. DRIFTS of reaction patterns.

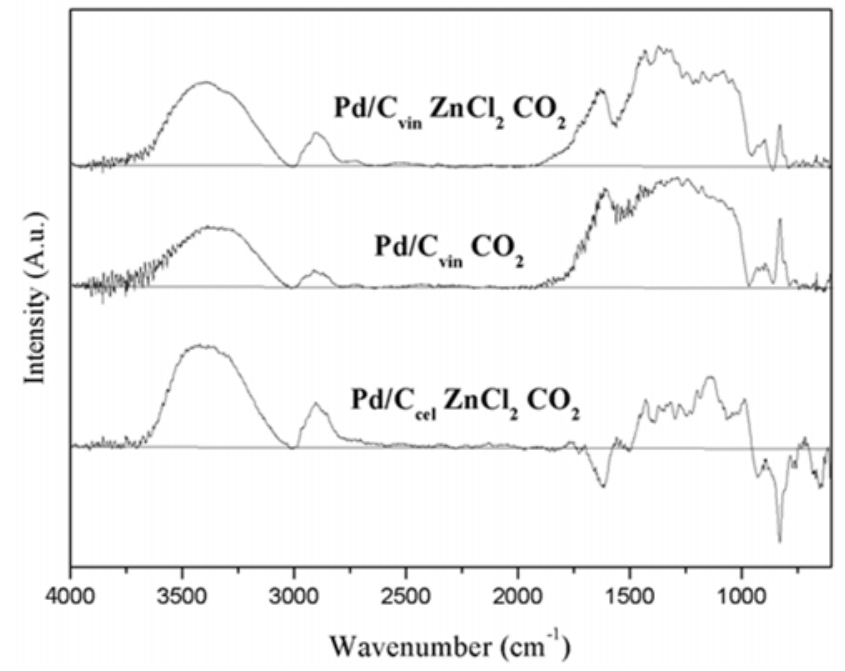




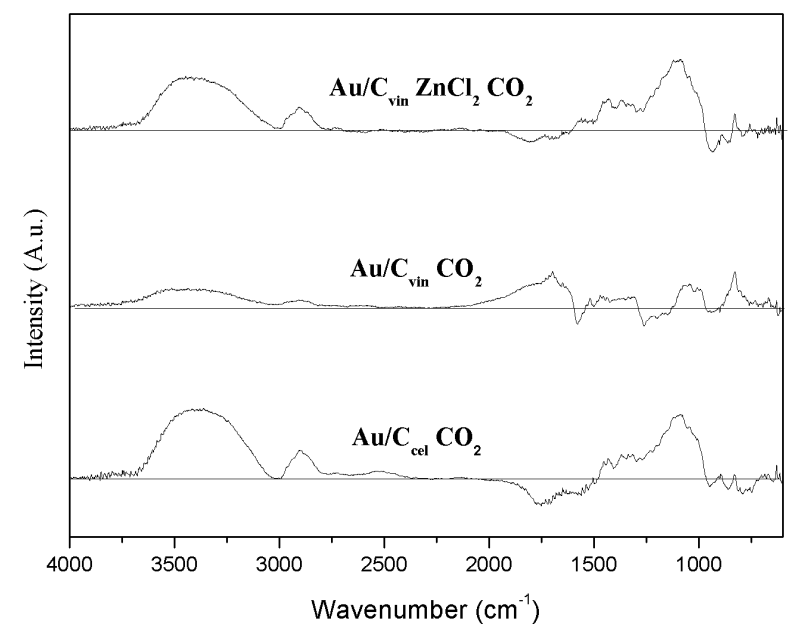

Fig. S2. DRIFTS difference spectra of palladium and gold catalysts. 